Harran Üniversitesi İlahiyat Fakültesi Dergisi

ISSN 1303-2054 | e-ISSN 2564-7741

Yıl: 26, Sayı: 44, Temmuz-Aralık 2020

\title{
EVS ŞAIRi KAYS B. EL-HATîM'iN ŞiiRLERINDE ÖVÜNME
}

\section{EGOTISM IN THE POEMS OF K়AYS B. AL-KHATTIM POET OF THE AWS \\ TRIBE}

\author{
Dr. Öğr. Üyesi Mehmet YILMAZ \\ myilmaz93@hotmail.com \\ Orcid ID: https://orcid.org/0000-0002-8223-7065 \\ Çanakkale Onsekiz Mart Üniversitesi Illahiyat Fakültesi \\ Temel İslam Bilimleri, Arap Dili ve Belagatı Ana Bilim Dalı \\ Çanakkale/Türkiye
}

Atıf@ Yılmaz, Mehmet. “Evs Şairi Kays b. el-Hatîm'in Siirlerinde Övünme”. Harran Üniversitesi Ilahiyat Fakültesi Dergisi 44 (Aralık, 2020), 175-200.

Makale Bilgisi / Article Information

Makale Türü / Article Types : Araştırma Makalesi / Research Article

Geliş Tarihi / Received : 29 Ekim 2020 / 29 October 2020

Kabul Tarihi / Accepted : 2 Aralık 2020 / 2 December 2020

Yayın Tarihi / Published : 15 Aralık 2020 / 15 December 2020

Sayı-Issue $\quad: 44$

Sayfa / Pages $\quad: 175-200$

DOI $\quad$ : https://doi.org/10.30623/harranilahiyatdergisi.818223 


\section{Öz}

Kays b. el-Hatîm (ö. 620), Câhiliye döneminin sonlarına doğru Medine'de dünyaya gelmiş ve Evs kabilesi arasında yetişmiştir. Kays b. elHatîm, usta savaşçı olduğu kadar şiir becerisinde de ileri seviyededir. İslâm'dan hemen önce Evs ve Hazrec kabîleleri arasında yaşanan savaşların çoğuna tanık olmuş ve mensubu bulunduğu Evs kabilesini hem silah hem de şiir yoluyla Hazrecliler karşısında savunmuştur. Bu bakımdan şair Evs kabilesiyle övündüğü beyitlerle de meşhurdur. Ülkemizde şairle ilgili müstakil çalışmalara rastlanmamaktadır. Bu sebeple şaire ait şiir metinlerinde övünme içerikli beyitler çalışma konusu yapılmıştır. Çalışma, İslâm öncesi dönemde Yesrib adıyla bilinen Medine-i Münevvere'nin sosyal ve kültürel yapısıyla ilgili ipuçları barındırması bakımından da önem arz etmektedir. Çalışmada ilgili beyitlere başta şaire ait Dîvân olmak üzere edebiyat, eleştiri ve rivayet içerikli bazı temel kaynaklar taranmak suretiyle ulaşılmıştır. Beyitler kişisel övünme ve kabileyle övünme adlarıyla iki alt başlık altında incelenmiştir. Beyitler Türkçe'ye tercüme edilmiş, gerekli açıklamalar yapılmış ve yer yer tahlil edilmiştir. Varılan kanaatler sonuç kısmında belirtilmiştir.

Anahtar Kelimeler: Arap Dili ve Belâgatı, Kays b. el-Hatîm, Şiir, Övünme, Evs Kabîlesi.

\section{Abstract}

Ḳays b. Al-Khațim (d. 620) was born in al-Madinna towards the end of the Jahiliyya period and was raised among the Aws tribe. Kays b. Al-Khațim was a skilled poet as well as a great warrior. He witnessed most of the wars fought between the Aws and Khazraj tribes just before Islam and defended the Aws tribe, of which he was a member, against the Khazraj, both through weapons and poetry. Thus, the poet was also famous for the couplets he exalted the Aws tribe. In our country, there are no individual studies about the poet. For this reason, the subject of this study is centred upon egoist couplets in his poetry. The study is also important in that it presents data about the social and cultural structure of al-Madina known as Yathrib in the pre-Islamic period. By scanning certain main sources of literature, criticism and narration, especially the Diwan of the poet, the study found significant couplets. The couplets have been examined under two subheadings: egotism and tribal pride. The couplets have been translated into Turkish, annotated and analyzed when necessary. The findings reached are presented in the conclusion part.

Keywords: Arabic Language and Rhetoric, Kays b. Al-Khațim, Poetry, Egotism, The Aws Tribe. 


\section{Giriş}

Günümüze ulaşan Câhiliye Arap şiirleri, İslâm öncesi dönemin sosyal, siyasal ve kültürel yapısı hakkında ipuçları barındırmaktadır. Zira şair, kişiliğini kazandığı ve kültürüyle yoğrulduğu toplumda deneyim sahibi olmakta ve duygularını beyitlere dökmektedir. İbn 'Abbâs bu bağlamda şöyle der:" "Bana Kur'ân'da yer alan garip lafızları sorarsanız anlamlarını şiirde arayınız derim. Zira şiir Arapların sicil defteridir." Hz. Peygamber'in şu ifadeleri de bu duruma işaret etmektedir: ${ }^{2}$ "Deve, yavrusuna özlem duymaktan vazgeçmedikçe, Araplar şiir söylemekten geri durmazlar." İslâm öncesi dönemde Yesrib adıyla bilinen Medîne-i Münevvere'de yaşamış olan Kays b. el-Hatîm'e ait şiirler de Yesrib kentinin sosyal ve kültürel yapısı hakkında ipuçları barındırmaktadır. Usta savaşçı olan Kays b. el-Hatîm, mensubu bulunduğu Evs kabîlesini düşman karşısında hem silah hem de şiir yoluyla savunmuştur. Şair bunu yaparken zaman zaman savaş sırasında yaşanan olayların detaylarına da inmektedir. Bu bakımdan şair yaşanan olaylar karşısında Evs kabîlesini savunduğu ve Evs kabîlesiyle övündüğü beyitlerle de meşhurdur. Illgili beyitlere başta şaire ait Dîvân olmak üzere Kuraşî’nin (ö. 170/786) Cemhere'si, Cumahî'nin (ö. 231/846) Tabakât'ı, İsfâhânî'nin (ö. 356/967) Kitâbu'lagânĩsi, Merzubânî'nin (ö. 384/994) Mu'cemu'ş-şu'arâ'sı, Kayravânî'nin (ö. 456/1064) el-'Umde'si, Tebrîzî'nin (ö. 502/1109) Şerhu Dîvâni'l-hamâse'si, 'Askalânî'nin (ö. 852/1449) el-isâbe'si ve Bağdâdî'nin (ö. 1093/1682) Hızânetu'ledeb'i gibi edebiyat, eleştiri ve rivayet muhtevalı temel kaynaklar taranmak suretiyle uşalılmıştır.

Şaire ait şiirlerde övünme muhtevalı beyitlere geçmeden önce konunun daha iyi anlaşılması bakımından şairin hayatı ve eski Arap şiirindeki yeri hakkında ön bilgiler vermek uygun olacaktır.

\section{Kays b. el-Hatîm'in Hayatı}

Tam adı Kays b. el-Hatîm b. 'Adiyy b. Sevâd b. Zafer b. Ka'b b. el-Hazrec b. en-Nebît b. Mâlik b. el-Evs'dir. ${ }^{3}$ Ebû Yezîd künyesiyle de bilinen ${ }^{4}$ şair Yesrib'de mukîm Evs kabîlesinin Benî Zafer koluna mensup olup Câhiliye devrinde dünyaya gelmiştir. ${ }^{5}$ Günümüze ulaşan kaynaklarda şairin doğum tarihi hakkında bilgiye rastlanmamaktadır. Hal böyle olmakla birlikte Hz. Peygamber'in Mekke'den Medine'ye hicretinden iki yıl önce 620 yılında vefat etmiş olması ${ }^{6}$ dikkate alındığında Câhiliye devrinin sonlarına doğru dünyaya geldiğini söylemek mümkün gözükmektedir. Şair henüz dünyaya gelmeden önce dedesi 'Adiyy, 'Abdulkays kabîlesine mensup bir şahıs tarafından öldürülür. Şair henüz küçük yaşta iken

1 el-Kurtubî, Ebû 'Abdillâh Muhammed b. Ahmed b. Ebî Bekr, el-Câmi' li ahkâmi'l-Ḳur'ân, thk. 'Abdullâh b. 'Abdulmuhsin et-Turkî (Beyrut: Muessesetu'r-Risâle, 2006) 1/44

2 İbn Raşîk, Ebû Ali el-Hasen el-Kayravânî, el-'Umde fí mahâasini'ş-şi'r ve âdâbihi ve naḳdih, thk. Muhammed Muhyiddîn Abdulhamîd (Beyrut: Dâru'l-Cîl, 1981), 1/31.

${ }^{3}$ el-Merzubânî, Ebû 'Ubeydillâh Muhammed b. 'İmrân, Mu'cemu'ş-şu'arâ', tsh. F. Krenkov (Beyrut: Dâru'I-Kutubi'I-'ilmiyye,1982), 321.

${ }^{4}$ el-İsfâhânî, Ebu'I-Ferec, Kitâbu'I-ağânî, thk. İbrahim es-Se'âfîn vd., (Beyrut: Dâru Sâdır, 2008), 3/5.

${ }^{5}$ Kays b. el-Hatîm, Dîvân, thk. Nasıruddîn el-Esed (Beyrut: Dâru Sâdır, ts), 11; İsmail Durmuş, "Kays b. Hatîm", Türkiye Diyanet Vakfı İslâm Ansiklopedisi (Ankara: TDV Yayınları, 2002), 25/92.

${ }^{6}$ ez-Ziriklî Hayruddîn, el-'Alâm (Beyrut: Dâru'l- 'Illm Li'I-Melâyîn, 2002), 5/205. 
babası Hatîm de Hazrec kabîlesine mensup Mâlik adında bir şahıs tarafından öldürülür. Annesinin terbiyesinde yetişen şair babasının katilini Medine'de, dedesinin katilini ise Zulmecâz denilen yerde yakalar ve öldürür. Bu sebeple Evs ve Hazrec kabîleleri arasında yıllar süren savaşlar meydana gelir. ${ }^{7}$ Şair bu savaşların bir kısmında hem kılıcı hem de şiirleriyle kabîlesini savunur ve kazandığı değerlerle ve kabîlenin sahip olduğu hasletlerle mısralarda sıkça övünür. Şair Allah Resûlü'yle Hac mevsiminde ${ }^{8}$ Mekke'de karşılaşır. Allah Resûlü tarafından İslâm'a davet edilse de daveti kabul etme hususunda tereddüt yaşar. Bir karara varabilmesi için $\mathrm{Hz}$. Peygamber'in Medine'ye hicret edeceği vakte kadar mühlet ister. ${ }^{9} \mathrm{Ne}$ var ki şair, hicretten önce ${ }^{10}$ Hazrecliler tarafından intikam amacıyla alınan bir karar doğrultusunda komploya kurban gider ve İslâm'a girmeden öldürülür. ${ }^{11}$

\section{Eski Arap Şiirindeki Yeri}

Kays b. el-Hatîm usta şairler arasındadır. Mensubu bulunduğu Evs kabîlesini düşman karşısında hem silah hem de şiir yoluyla savunmuş olması bu duruma işaret etmektedir. 'Ukâz Panayırı'nda düzenlenen şiir etkinliklerinde hakemlik yapan meşhur eleştirmen ${ }^{12}$ Nâbiğa (ö. 605) tarafından "Insanların arasında en usta şair sensin" diyerek Kays b. el-Hatîm'e taltifte bulunulmuş olmasi ${ }^{13}$ da yine bu duruma işaret etmektedir. Kays b. el-Hatîm ile Hassân b. Sâbit (ö. 60/680) ${ }^{14}$ ve Abdullah b. Ravâha (ö. 8/629) 15 $^{15}$ arasında yaşanan şiir atışmaları meşhurdur. Dahası Hassân b. Sâbit, "Araplarla savaşmamız gerektiğinde kaliteli şiirlerimizi ortaya koymak isterdik ve Kays b. el-Hatîm'in şiirlerine başvururduk"16 diyerek Kays b. el-Hatîm'e ait şiirlerin kalitesine vurgu yapmaktadır. Cumahî, Tabakât'ında Kays b. el-Hatîm'i Kentli şairler arasında Medine'den dördüncü şair olarak sıralamaktadır. ${ }^{17}$ Kuraşî de Cemhere'sinde Muzehhebât adını verdiği bölümde şairi kaliteli şairler arasında dördüncü sıraya koymaktadır. ${ }^{18}$ Dilciler, nahiv âlimleri ve

7 İsfâhânî, Kitâbu'l-ağânî, 3/5; Abkarius, İskender Ağa, Kitâbu Ravdati'l-edeb fî tabakâti şu'arâi'l'Arab (Beyrut: byy., 1858), 251.

8 İbn Sellâm, Muhammed el-Cumahî, Tabakâtu fuhûli'ş-şu'arâ', thk. Mahmûd Muhammed Şâkir (Cidde: Dâru'l-Medenî, ts.), 1/230-231.

${ }^{9}$ el-'Askalânî, Ahmed b. Ali b. Hâcer, el-isâbe fî temyîzi's-sahâbe, thk. Abdullah b. Abdu'l-Muhsin etTurkî (Kahire: Merkezu Hecr Li'l-Buhûs ve'd-Dirâsâti'l-'Arabiyye Ve'l-i̇slâmiyye, 2008), 13/296; elAsfâhânî, Kitâbu'l-ağânî, 3/10.

${ }^{10}$ Abkarius, Kitâbu Ravdati'l-edeb, 252.

11 el-Bağdâdî, 'Abdulkâdir b. 'Umar, Ḧızânetu'l-edeb, thk. 'Abdussellâm Hârûn (Kahire: Mektebetu'IHâncî, 1996), 7/37.

12 Tâha, Ahmed ỉbrâhîm, Târîhu'n-nakdi'l-edebî 'inde'I-'Arab (Mekke: Mektebetu'I-Faysaliyye, 1937), 25.

13 el-i̇sfâhânî, Kitâbu'l-ağânî, 3/10.

${ }^{14}$ Sözgelimi bkz: Hassân b. Sâbit, Dîvân, thk. 'Abd Muhanna (Beyrut: Dâru'I-Kutubi'I-'ilmiyye, 1994), 168-169.

15 el-Kuraşî, Ebû Zeyd Muhammed b. Ebi'l-Hattâb, Cemheretu eş'âri'l-'Arab fi'l-Câhiliyyeti ve'I-Islâm, thk. Muhammed 'Ali el-Hâşimî (Riyad: İmam Muhammad bin Sa'ud Islamic University, Comitte of Researc, Translation and Publication, 1981), 2/629.

${ }^{16}$ Merzubânî, Mu'cemu'ş-şu'arâ', 321-322.

17 ỉbn Sellâm, Tabakâat, 1/ 215.

18 Kuraşî, Cemheretu eş'âri'I-'Arab, 2/645. 
coğrafya bilginleri Kays b. el-Hatîm'in şiirlerinden istişhâdlar yapmışlardır. ${ }^{19}$ Görüldüğü üzere Kays b. el-Hatîm şiir becerisinde hatırı sayılır konuma haizdir.

\section{3. Şiirlerinde Övünme}

Sözlükte iftihar kaynağı anlamına gelen övünme ${ }^{20}$, zorlukla elde edilebilecek kazanımların kişide var olduğu iddiası üzerine kurulur. ${ }^{21}$ Zira çöl ikliminin beraberinde getirdiği şartlar altında güç bela hayata tutunmaya çalışan bedevî toplumlarda hamiyet, gurur, onur, taassup, cesur olma ve zoruklara tahammül edebilme gibi hasletler takdire şayan değerlerdir. ${ }^{22}$

Lirik şiir türü olan fahr/övünme, Câhiliye devri Arap şiirlerinde sıkça rastlanan temalardandır. Arap şairler, övünme temalı beyitleri sahip oldukları erdemleri ve toplumdaki hatırı sayılır konumları dile getirme aracı olarak kullanmışlardır. Şairler kendilerinde ve mensubu bulundukları kabîlelerde var olan cesaret, düşman karşısında ustaca savaşma, şiir becerisi, cömertlik ve kabîlenin parlak geçmişi gibi hasletlerle beyitlerde övünmüşlerdir. ${ }^{23}$ Özellikle şair, kabîlenin hem sözcüsü hem de düşmana karşı yürütülen psikolojik savaşta savunucusu konumundadır. ${ }^{24}$ Bu bakımdan erken dönem şiir eleştirmenleri şiir temalarını nesîb ${ }^{25}$, medih, hiciv, övünme ve vasf olmak üzere beş kısımla sınırlandırmışlardır. ${ }^{26}$

Kays b. el-Hatîm'e ait şiir metinlerinde de övgü temalı beyitlere rastlanmaktadır. İlgili beyitleri kişisel ve kabîleyle övünme şeklinde iki alt başlıkta incelemek mümkündür.

\section{1. Kişisel Övünme}

Şair cesaret, el açıklığı, fizikî yapı ve erdem gibi şahsında var olan hasletlerle beyitlerde övünmektedir.

\section{1. 1. Cesaret}

Tehlikelerin üzerine korkusuzca gitme şevki ${ }^{27}$ ve cüretkâr olma anlamlarına gelen cesaret, kabîlenin takdire değer şahsiyetlerinde bulunması gereken önemli özellikler arasındadır. ${ }^{28}$ Zira Câhiliye toplumlarında hayat, genel anlamda kabîleler arasındaki çekişmelerle ve durmak bilmeyen savaşlarla doludur. Hayata

${ }^{19}$ Celîl, Hasen Muhammed, Kays b. el-Hatîm hayâtuh ve şi'ruh (Amman: Dâru Dicle, ts.), 167-171.

20 ibn Manzûr, Lisânu'I-'Arab, (Kahire: Dâru'I-Ma'ârif, ts), 5/ 3361. (Fâ Bâbı)

21 el-Cundî, 'Ali, Şi'ru'l-ḥarb fi'l-'asri'l-câhilî (Beyrut: Dâru Mektebeti'l-Câmi'ah el-'Arabiyye, 1966), 363.

22 Tuleymât Gâzî ve el-Aşkar, 'İrfân, el-Edebu'I-câhilî ḳadâyâhu ağrâduh a'lâmuh funûnuh (Dimaşk: Mektebetu'l-Îmân, 1992), 135.

23 'Abdunnûr, Cebbûr, el-Mu'cemu'I-edebî, (Beyrut: Dâru'I-'ilm Li'I-Melâyîn, 1984), 189.

24 Hassân b. Sâbit, Dîvân, 113.

25 Nesîb, şair tarafından kadınların fizikî özellikleri, ahlâkî davranış biçimleri ve kadınlara olan tutkuların beyitlerde dile getirilmesi anlamındadır. Bkz. Vehbe, Mecdî ve el-Muhendis, Kâmil, Mu'cemu'I-mustalahâti'I-'Arabiyye fi'l-lugati ve'l-edeb, (Beyrut: Mektebetu Lubnân, 1984), 410.

26 Ibn Raşîk, el-'Umde, 1/121.

27 el-'Askerî Ebû Hilâl, el-Furûk el-luğaviyye, thk. Muhammed ibrâhîm Selîm (Kahire: Dâru'I-'ilm ve'sSekâfe, 1997), 108, 109.

28 el-Faysal, 'Abdul'azîz b. Muhammed, el-Edebu'l- 'Arabî ve târîhuh, (Riyad: Câmi'atu'l-İmâm Muhammed b. Su 'ûd el-i̇slâmiyye, 1405), 41. 
tutunabilmek için düşmanla savaşmak mukaddes sayıldı̆̆ından ${ }^{29}$ savaş becerisinde usta bireyler saygın kimseler olarak telakkî edilmektedirler. Kabîlede herkesin uyması gereken en önemli kural hasım kabîle tarafından öldürülenlerin intikamını almaktır. ${ }^{30}$ Erken dönem şiir eleştirmenlerinden Kudâme b. Ca'fer (ö. 337/948), hayata tutunabilme mücadelesindeki önemi sebebiyle cesaretli olmayı akıl, adalet ve iffetle birlikte kişide bulunması gereken en önemli dört haslet arasında zikretmektedir. ${ }^{31}$

Kays b. el-Hatîm'e ait beyitlerde de cesaretle övünmenin örneklerine rastlanmaktadır. Dedesi 'Adiyy ile babası Hatîm'in intikamını aldıktan sonra söylediği beyitler bu duruma iyi bir örnektir. Şair dedesinin ve babasının intikamını korkusuzca almakla övündüğü beyitlerde şöyle der: ${ }^{32}$

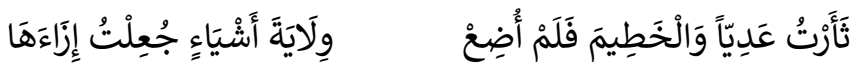

'Adiyy ve el-Hatîm'in intikamını aldım da sorumluluğu şahsıma tevdi edilen hususuların hakkını boşa çıkarmadım.

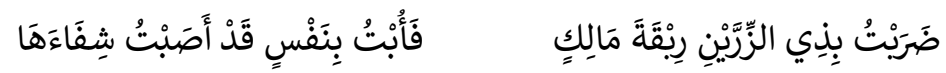

iki yanı keskin kılıçla Mâlik'in boynunu vurdum. Böylece içimdeki intikam ateşini söndürdüm ve (nihayet) kendime geldim.

$$
\text { وَسَامَحَنِي فِيهَا ابْنُ عَمْرِو بْنِ عَامِرٍ خِدَاشُ فَأَدَّى نِعْمَةً وَأَفَاءهَا }
$$

Bunu yaparken 'Amr b. 'Âmir'in oğlu Hıdâş3 da (dedem 'Adiyy ile babam elHatîm'in intikamını almam hususundaki yardım talebimi) anlayışla karşılayarak bana büyük bir iyilik yaptı. (Böylece) iyi bir fırsat yakalamamı sağladı.

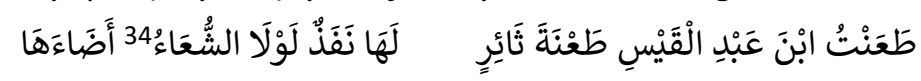

ibn 'Abdi'l-Kays'a ${ }^{35}$ kan davası güdercesine öyle bir (mırrak) ${ }^{36}$ sapladım ki akan alkan olmasa yara alan bölge ortaya çıkardı.

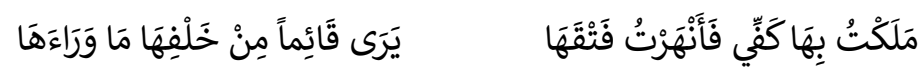

29 Ebu'r-Rabb, İbtisâm Nâyif Sâlih, Suvaru'l-harb ve eb'âduha'l-ustûriyye fi'ş-şi'ri'l-câhilî, (Yüksek Lisans Tezi, Câmi'atu'n-Necâh el-Vataniyye, Nablus, 2006), 30

${ }^{30}$ Dayf, Şevkî, Târîhu'l-edebi'l-'Arabî el-'Asru'I-câhilî (Kahire: Dâru'I-Ma'ârif, 1960), 62.

${ }^{31}$ Kudâme b. Ca'fer, Naḳdu'ş-şi'r, thk. Muhammed 'Abdulmun'im Hafâcî (Beyrut: Dâru'I-Kutubi'l'ilmiyye, ts.), 96.

32 Kays b. el-Hatîm, Dîvân, 43-50.

33 Beyitte adı geçen Hıdâş, meşhur Arap şairi Hıdâş b. Zuheyr'dir. Bkz. el-Merzubânî Mu'cemu'şşu'arâ',107. Hıdâş aynı zamanda Kays b. el-Hatîmin dedesini öldüren 'Adiyy'in de amcasının oğludur. Toplumda saygın bir şahsiyet olan Hatîm, öldürülmeden önce Hıdaş'a yardım eli uzatmıştır. Bu sebeple şair dedesinin ve babasının intikamını almak için Hıdâş'tan yardım ister. Hıdâş bu isteği geri çevirmez ve şaire amcasının oğlu ile babasının bulunduğu yeri gizlice gösterir. Geniş bilgi için bkz. et-Tebrîzî, Ebû Zekeriyâ Yahyâ b. 'Ali el-Hatîb, Şerḥu Dîvâni'l-ḥamâse, thk. Muhammed Muhyiddîn el-Hatîb (Kahire: Matba'atu Hicâzî, 1938), 1/180.

${ }^{34}$ Beyitte yer alan الشعاء lafzı alkan anlamındadır. Bkz. Kays b. el-Hatîm, Dîvân, 46.

${ }^{35}$ Beyitte adı geçen İbn 'Abdi'l-Kays, Kays b. el-Hatîm'in babasını öldüren şahıstır. Bkz. el-Bağdâdî, HIzânetu'l-edeb, 7/37.

${ }^{36}$ Şair hasmını mızrak darbesiyle öldürmüştür. Bkz. Kays b. el-Hatîm, Dîvân, 52. 
Yara alan bölgeyi elimle iyice kavradım da kanın bolca akması için daha da parçaladım. Yara o kadar açılmış ve yırtılmışı ki ayakta duran kimse yaranın arka tarafını gör(ebil)mekteydi.

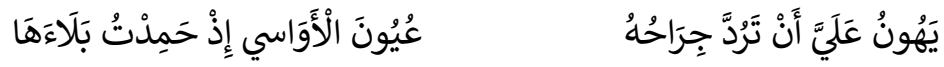

Yara alan bölgeye pansuman yapan kadınların (ürkütücü görüntü karşısında) gözlerini başka yönlere çevirmek durumunda kalmalarına aldırmıyorum (hasmıma) böyle bir felaketi yaşatma fırsatı yakaladığım için hamd ettiğim bu vakitte.

$$
\text { وَكُنْتُ امْرءاً لَأَسْمَعُ اللَّهْرَ سُبَّةَ }
$$

Hayatta (dedemin ve babamın öldürüldüğü ve intikamlarını almam gerektiği yolunda) şahsıma dil uzatıldığı ağır söz duymamış bir kimse idim. Ta ki üzerindeki sır perdesini aralayıncaya kadar. ${ }^{37}$

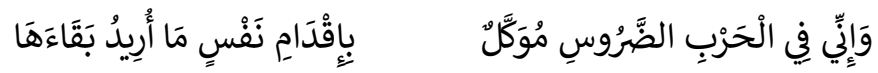

Şüphesiz zorlu savaşta sağ çıkmamak üzere cesaretle (düşman) üzerine atılmakla yükümlüyüm

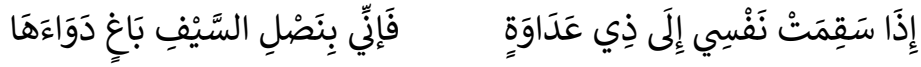

Canım düşmanla çarpışma hastalığına yakalandığında tedavisini kılıcın kabzasını (sımsıkı tutarak) saldırmakta bulurum.

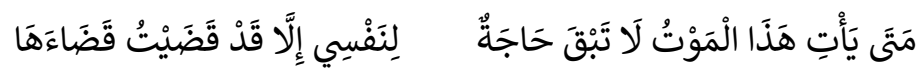

Ne zaman ölüm anı karşıma çıksa canımın arzuladığı hiçbir şeyi (er meydanında) ardına koymam.

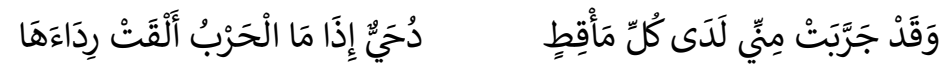

Duhayy (kabîlesi) her daim savaş krizinin patlak verdiği ve savaşın bütün çıplaklığıyla kızıştığı zor anlarda (cesurca vuruşlarımı elbet) tecrübe etti.

Beyitlerden de anlaşılacağı üzere şair, dedesinin ve babasının intikamını almayı yerine getirilmesi gereken bir görev kabul etmekte ve görevini vakit kaybetmeden uygulamaya koyulmaktadır. Zira hasım kabîle tarafından öldürülen kabîle bireylerinin intikamını almak, kabîleyi koruyacak savaşçıda ${ }^{38}$ bulunması

37 Şair, babası öldürüldüğünde henüz olan bitenleri anlayamayacak kadar küçüktür. Annesi küçük Kays'ı koruma içgüdüsüyle hareket eder ve ileride dedesi ile babasının intikamını almaya kalkışmasından endişe duyar. Zira oğlunun sonu gelmeyecek kan davasına bulaşması bir şekilde öldürülmesini kaçınılmaz kılacaktır. Bu sebeple ikamet ettikleri evin önüne kabir görüntüsünde iki çukur kazar ve Kays'a çukurların dedesiyle babasına ait iki kabir olduğunu söyler. Kays delikanlılık çağına geldiğinde Zafer aşîretinden genç bir adamla tartışır. Genç adam Kays'a "Delikanlı olsan gücünü dedenin ve babanın katilleri üzerinde denerdin. Benimle cedelleşmek yerine git sana yakışanı yap!" der. Kays bu söze içerler ve soluğu annesinin yanında alır. Annesinden dedesinin ve babasının akıbetleri hususunda kendisine doğruları söylemesi gerektiğini yoksa intihara kalkışacağı veya annesini öldüreceği yolunda tehditler savurur. Çaresiz kalan anne Kays'a olanları anlatır. Dedesi ile babasının öldürüldüğünü öğrenen Kays, vakit kaybetmeden intikamlarını almak üzere yola koyulur. Şair, Hıdâş b. Zuheyr'in de yardımıyla katillere ulaşır ve her ikisini de farklı aralıklarla öldürür. Geniş bilgi için bkz. et-Tebrîzî, Şerhu Dîvâni'l-ḥamâse, 1/180.

${ }^{38}$ Cundî, Şi'ru'l-harb fi'l-'asri'l-câhilî, 95. 
gereken en önemli özelliklerden biridir. ${ }^{39}$ Şair düşmanla karşı karşıya gelmek mecburiyetinde kaldığı vakitlerde ise kahramanca savaşmakta ve savaşın sonunda ganimetlerden dilediğini elde etmektedir. Zira şair ölümü pahasına da olsa düşman karşısında yenilmeyi ve zillet hayatı yaşamayı kabullenmemektedir. Şair gözü pek olduğunu vurguladığı beyitlerde bu duruma işaret etmekte ve şöyle demektedir: ${ }^{40}$

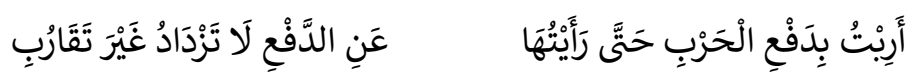

Savaştan uzak durulmasını arzuladım. Ta ki (savaşın) daha da yaklaşmakta olduğunu ve (ancak vuruşarak) savuşturulması gerektiğini fark edinceye kadar.

$$
\text { فَإِذَا لَمْ يَكُنْ عَنْ غَايَةِ الْمَوْتِ مَدْفَحُ فَأَهْلاً بِهَا إِذْ لَمْ تَزَلْ فِي الْمَرَاحِبِ }
$$

Eğer (er meydanlarında) ölmekten başka çare kalmamış ise savaş hoş gelmiş safalar getirmiştir.

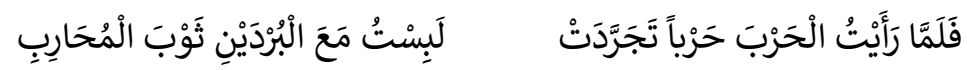

(Nitekim) savaşın bütün çıplaklığıyla kızıştığını görünce iki hırkayla birlikte savaşşı elbisesi ${ }^{41}$ (olan zırhı da) giydim.

Görüleceği üzere şair, savaşmaktan başka çare kalmadığı durumlarda zillet içerisinde bir hayat yaşamak yerine seve seve ölüme gitmeyi tercih etmektedir. Şair ne pahasına olursa olsun ölümden bir şekilde uzak durmaya çalışan kimseleri eleştirmekte ve şöyle demektedir: ${ }^{42}$

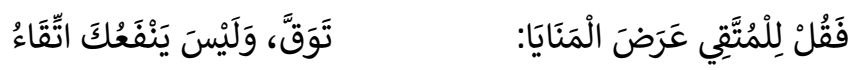

Ölüme neden olacak hadiselerden sakınmaya çalışan kimseye de ki: Sen sakınmana bak! (Ama bil ki) sakınma sana fayda vermeyecektir.

Son olarak şair ölüme fütursuzca atılması sebebiyle kendisine eleştiri oklarını yönelten muhtemelen eşi olan bir kadına karşılık vermekte ve bu duruma gerekçe olarak yaşanan haksızlıkları göstermektedir. Şair bu bağlamda şunları söylemektedir: ${ }^{43}$

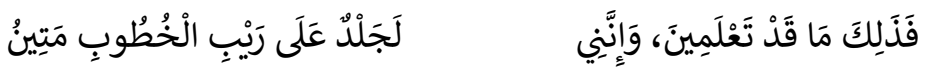

Bu durumun aslı senin de bildiğin üzere şöyledir: Ben zorluklar karşısında yılmak bilmem (aynı zamanda) güçlüyüm de.

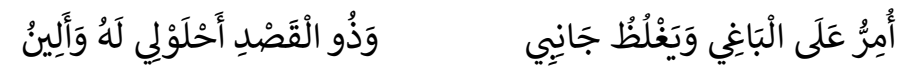

Haddi aşanın karşısında acı ve sert olurum. Insaf sahibine ise tatlı ve yumuşak başlı.

Beyitlerden de anlaşılacağı üzere şair haddi aşan hasımları karşısında oldukça sert iken halkı tarafından sevilmektedir. Zira şair insaf sahibi kimselerle bir araya geldiğinde mütevazı ve yumuşak başlıdır. Sâbit b. Kays b. Şemmâs (ö.

\footnotetext{
${ }^{39}$ Kudâme b. Ca'fer, Naḳdu'ş-şi'r, 98.

${ }^{40}$ Kays b. el-Hatîm, Divân, 81- 82.

${ }^{41}$ Beyitte yer alan ثوب المحارب ifdesiyle zırh kastedilmektedir. Bkz. Kays b. el-Hatîm, Dîvân, 82.

42 Kays b. el-Hatîm, Dîvân, 157.

${ }^{43}$ Kays b. el-Hatîm, Dîvân, 166.
} 
11/632) tarafından Allah Resûlü'nün huzurunda Kays b. el-Hatîm'in haksızlık karşısında gözü pek olduğu yolunda yaptığı tanıklık da bu duruma işaret etmektedir. Allah Resûlü, sadece Hazrec kabîlesine mensup şahsiyetleri barındıran bir mecliste Kays b. el-Hatîm'e ait şu mısra ile başlayan şiirin okunmasını ister: ${ }^{44}$

$$
\text { أَتَعْرِفْ رَسْماً كَاطِّرَادِ الْمَذَاهِبِ }
$$

(Bir zamanlar) boydan boya altınla işlenmiş gibi (ihtişamlı iken şimdi) hiçbir bineklinin (yanında) duraklamadığı 'Amra'ya ${ }^{45}$ ait viran (olmuş yapıdan geriye kalan silik) izi tanır mısın?

Mecliste bulunanlardan biri ayağa kalkar ve Kays b. el-Hatîm'in ilgili şiirini şu beyite kadar okur:

$$
\text { أُجَالِدُهُمْ يَوْمَ الْحَدِيقَةِ حتاسِراً }
$$

Hadîka Günü ${ }^{47}$ onlarla miğfersiz çarpışıyor(du)m. Kılıç tutan elim adeta oyun oynayan (çocuğun elindeki dürülmüş mendil) gibiydi.

Allah Resûlü meclise döner ve "Söylediği gibi miydi?" buyurur. Sâbit b. Kays b. Şemmâs ayağa kalkar ve Allah Resûlü’ne: “Ey Allah'ın Resûlü! Seni hak ile gönderen Allah'a yemin olsun ki; gerçekten o, damat olduğunun yedinci gününde üzerinde gecelik ve süslü bir yorganla karşımıza çıktı da söylediği gibi bizimle dövüştü" diyerek haksızlık karşısında gösterdiği cesareti doğrular. ${ }^{48}$

\section{1. 2. Cömertlik}

Cömertlik, Arap toplumlarında örnek alınması gereken en esaslı erdem ve davranış biçimleri arasında yer alır. ${ }^{49}$ Kays b. el-Hatîm'e ait şiirlerde de şairin el açıklığıyla övündügü beyitlere rastlanmaktadır. Söz gelimi şair zorlukla elde edilen birikmiş malın geçici olduğuna vurgu yapmakta ve beyitlerde şöyle demektedir: ${ }^{50}$

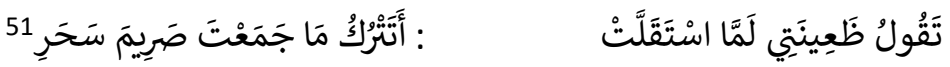

Eşim deve üzerindeki tahtırevana kurulmuş halde yola koyulduğu sırada (beni paylayarak) şöyle diyor(du): "(Zor şartlarda biriktirdiğin) bunca malı (saçıp savuruyorsun da tavsiyelerime kulak asmadan) ümitisce (başkalarına) $\mathrm{mı}$ bırakıyorsun?"

44 İsfâhânî, Kitâbu'l-ağânî, $3 / 9$.

${ }^{45}$ Beyitte adı geçen 'Amra, Abdullah b. Ravâha'nın kız kardeşi Ummu'n-Nu’mân b. Beşîr el-Ansârî'dir. Bkz. Kays b. el-Hatîm, Dîvân, 67.

46 Beyitte yer alan المخراق lafzı, çocukların oyunda birbirlerine vururken kullandıkları dürülmüş mendil vb. kumaş parçasının adıdır. Bkz. İbn Manzûr, Lisânu'l-'Arab, 2/ 1143. (Hı Bâbı)

47 Beyitte yer alan الحديقة Medine açıklarında Mekke'ye giden yol üzerinde bir köy ismidir. Kays b. el-Hatîm burada i̇slâm'dan önce Evs ve Hazrec kabîleleri arasında çıkan bir savaşa gönderme yapmaktadır. Bkz. el-Hamevî, Şihâbuddîn Yâkût b. 'Abdullah er-Rûmî, Mu'cemu'l-buldân, (Beyrut: Dâr Sâdır, 1977), 2/ 232.

48 İsfâhânî, Kitâbu'l-ağânî, $3 / 9$.

${ }^{49}$ Halebî, Semîr, el-Kerem ve'l-cûd ve's-sahâ (Tanta: Dâru's-Sahâbe Li't-Turâs, 1988), 4.

50 Kays b. el-Hatîm, Dîvân, 181- 182.

51 Beyitte yer alan صريم سحر ifadesi "ümitsizce" anlamındadır. Bkz. el-Câhız, Ebû 'Usmân 'Amr b. Bahr, el-Hayavân, thk. 'Abdussellâm Muhammed Hârûn (Kahire: Şeriketu Mektebeti ve Matba'ati Mustafa el-Bâbi el-'Halebî ve Evlâduh, 1965), 5/230. 


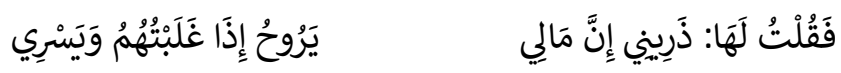

Ben de ona (cevabımda) şöyle diyorum: "Beni kendi halime bırak! Zira onlara karşısında üstün gelirsem malım gündüz (elimden çıkar) gider. Ancak gece olduğunda (yeniden kazanılarak geri) gelir."

Beyitlerden de anlaşılacağı üzere şair güç şartlarda biriktirdiği kazancını ihtiyaç sahibi kimselere harcaması sebebiyle eşi tarafından tenkit edilmekte ve bu davranıştan vaz geçmeye zorlanmaktadır. Ne var ki şair dünya malı gelip geçicidir mantığıyla hareket etmekte ve eşinin yakarışlarına kulak asmamaktadır. Şair bir başka beyitte yine cömertlikle övünmekte ve malın önemsiz olduğuna vurgu yaparak şöyle demektedir: ${ }^{52}$

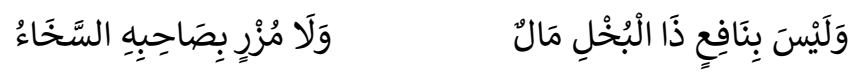

Mal ne cimri kimseye fayda verir ne de cömertin itibarını düşürür.

Şair zor şartlarda bile cömertlikten ödün vermemektedir. Kuşkusuz şairin bu davranışı, el açıklığının erdem kabul edildiği Câhiliye toplumlarında varlıklı kimselere kıyasla daha da anlamlıdır. Beyitlerde kendisine şahsi ihtiyacını karşılayacak erzak ayırmadığını dile getirmekte ve elinde avucunda ne varsa gerekli yerlere dağıttığını ifade ederek şöyle demektedir: ${ }^{53}$

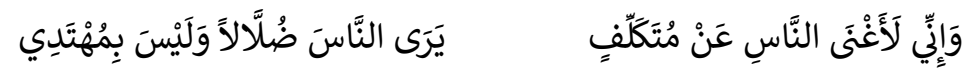

Doğrusu kendisi yanlış yolda iken insanların haktan saptığını sanan yapmacık kimselere en çok ben ihtiyaç duymam.

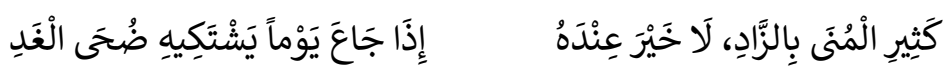

(Şu) erzak biriktirmeyi tutku haline getiren kimselere. (Şahsında bu özelliği barındıran) kimsede asla hayır yoktur. Bir gün aç kalsa ertesi gün kuşluk vaktinde hâlâ bu durumdan şikâyet eder.

Şair mal biriktirmeyi başlı başına amaç değil toplumda saygınlık elde etme aracı olarak görmektedir. ${ }^{54}$

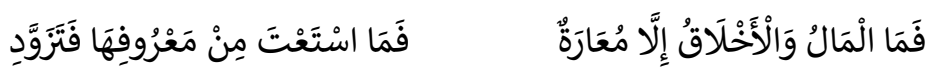

Mal da ahlâk da ödünç alınan borçtan öte bir şey değildir. Dolayısyıla mal ve ahlâkın itibar gören türünden gücün nispetinde azık edin.

Şaire göre kişi, birikimini har vurup harman savurarak değil doğru mecrada intiyaç sahibi kimselere harcaması durumunda saygınlık kazanacaktır. Şair bu bağlamda şöyle demektedir: ${ }^{55}$

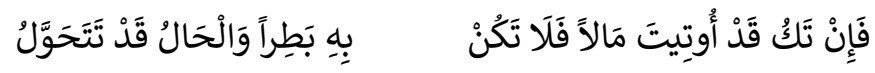

Sana birikim elde etmek nasip edilmiş ise sakın ola yanlış mecrada saçıp savurma. (Zira) şartlar her an değişebilir.

\footnotetext{
52 Kays b. el-Hatîm, Dîvân, 225.

53 Kays b. el-Hatîm, Dîvân, 128- 129.

54 Kays b. el-Hatîm, Dîvân, 130.

55 Kays b. el-Hatîm, Dîvân, 139.
} 
Şaire göre mal biriktirme hırsına kapılmış kimsenin zengin olması mümkün gözükmemektedir. Zira hırsına yenik düşmüş kimse çok kazansa bile gözü doymak bilmeyecektir. Şair esas zenginliğin gönül zenginliği olduğuna vurgu yaptığı beyitlerde şöyle demektedir: ${ }^{56}$

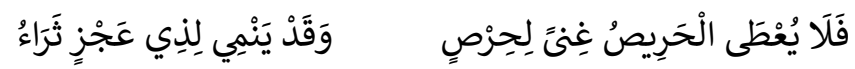

Hırslı kimseye hırsı sebebiyle zenginlik verilmez. (Kaldı ki) sınırlı imkâna sahip kimsenin de serveti artabilir.

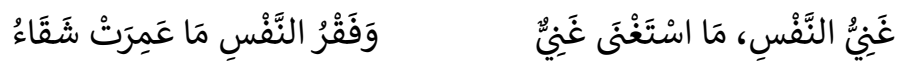

Gönlü zengin kimse her daim zengindir. Gönlü fakir ise ömür boyu bedbahttır.

Şair mal biriktirme hırsına kapılan ve malından harcamayan cimrilerle aynı kefeye konulmaktan sakınmaktadır. Bu sebeple aşiretini diğer mensuplarla birlikte kalkındırmak amacıyla yaptığı bağışlarla övünmekte ve beyitlerde şöyle demektedir: ${ }^{57}$

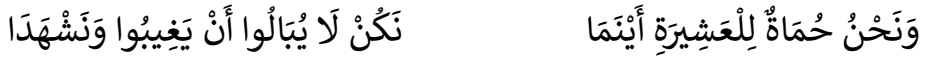

Her nerde isek hepimiz aşiretin hamileriyiz. (Aşîret bireylerinden) bazılarının uzakta bizim de yakında bulunuyor olmamızın hesabını yapmazlar.

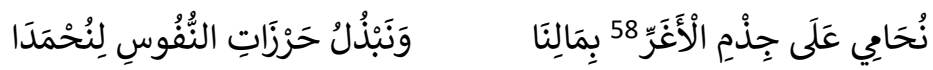

Malımızla (Mâlik) el-Ağarr'ın (soyundan gelen aşîretimizin) aslını savunuruz ve (bu uğurda takdir edilerek) övülmemiz amacıyla nefislere hoş gelen en değerli birikimlerimizi bağışlarız.

Yapılan izahlardan da anlaşılacağı üzere şaire göre dünya malı geçicidir ve toplumda saygınlık kazanma aracı olarak kullanılmaktadır. Şair zor şartlarda dahi cömertlikten ödün vermemekte ve elinde avucunda ne varsa ihtiyaç sahiplerine harcamaktadır. Zira şaire göre esas zenginlik gönül zenginliğidir. Mal biriktirme hırsının esiri olan kimse dilediği her şeyi elde etse bile gözü doymayacağından asla huzuru yakalayamayacaktır. Şair diğer aşîret mensuplarıyla birlikte aşîretin kalkınması amacıyla yaptığı bağışlarla hatırlanmayı amaçlamakta ve gelecek kuşaklara el açıklığı konusunda örnek olmayı arzulamaktadır.

\section{1. 3. Fizikî Yapı}

Kays b. el-Hatîm, dış görünümü itibarıyla iyi bir fiziğe sahiptir. Doğuştan var olan bu özellik sebebiyle kadınlar şaire hayranlık duymaktadırlar. ${ }^{59}$ Şair, kadınların fitnesinden korunmak amacıyla kafasına doladığı sarıkla karşılarına çıkmaktadır. ${ }^{60}$

\footnotetext{
56 Kays b. el-Hatîm, Dîvân, 157-158.

57 Kays b. el-Hatîm, Dîvân, 220-221.

58 Beyitte yer alan الأغر şairin mensubu bulunduğu aşîretin atasıdır. Bkz. ỉbn Hazm, Ebû Muhammed 'Ali b. Ahmed b. Sa'id, Cemheretu ensâbi'I-'Arab, thk. Kurul (Beyrut: Dâru'I-Kutubi'l- 'Illmiyye,1983), 363.

59 İsfâhânî, Kitâbu'l-ağânî, 3/10.

60 İbn Habîb, Ebû Ca'fer Muhammed, Kitâbu'I-Muhabbar, tsh. Eliza Lechten Stetter (Beyrut: Dâru'IÂfâki'l-Cedîde, ts.), s. 233.
} 
Şair dış görünümünü de beyitlere yansıtmakta ve bu özelliğiyle övünmektedir. Söz gelimi beyitlerde şöyle demektedir: ${ }^{61}$

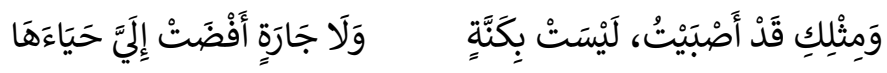

Aramızda sır perdesi bulunmayan senin gibi ne gelinim ne de komşum olan (nicelerni) kendime aşık ettim.

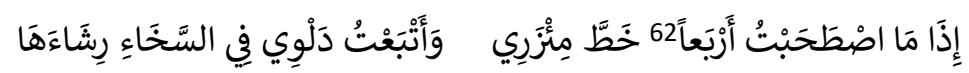

Dört kadeh içtiğimde (kendimden geçerim de) elbisemin eteğini böbürlenerek yerlerde sürürüm. ${ }^{63}$ Kendime geldiğimde (kuyuya iple kova sarkıtırcasına) kaldığım yerden devam ederek cömertliği sürdürürüm.

Şair, muhatabı gibi evli ve komşu olmayan çok sayıda kadınının kendisine âşık olduğunu dile getirmektedir. Bunu yaparken güzü pek olma gibi genç kızların çoğu defa hayranlık duyacakları genç erkeklere has bazı özellikleri de sıralamaktadır.

Şair bir defasında geçmişte aşk yaşadığı ve zamanla yollarının ayrıldığı genç bir sevgiliyle karşılaşır. Eski sevgili geçmişe kıyasla daha alımlı ve olgun gözükmektedir. Şair fiziki yapısıyla genç kızların gönüllerini fethettiği eski günleri hatırlar ve bu durumla övünerek şöyle der: ${ }^{64}$

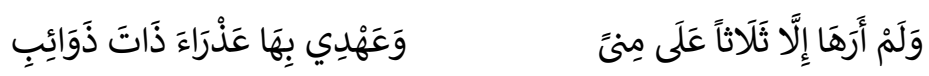

Sevgiliyi Mina'ya doğru yol alırken sadece üç defa gör(müş)tüm. O sıralar henüz erkeklerin dikkatini çekmeyecek kadar gelişmemiş zülüfleri tel tel olmuş toy bir kız idi.

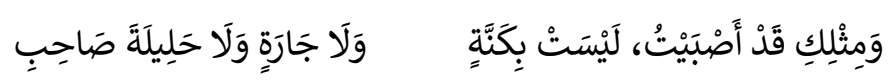

Senin gibi ne gelinim ne komşum ne de dostumun eşi olan (nicelerni) kendime aşık ettim.

Şair 'Amra adındaki bir başka sevgilinin de fizikî yapısı sebebiyle şaire olan tutkusunu beyitlere taşımakta ve bu durumla övünerek şöyle demektedir: ${ }^{65}$

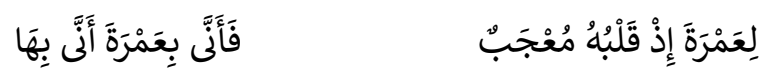

'Amra'ın gönlünü (bana) kaptırdığı uzun geceler oldu. Bana olan tutkusunu nasıl gizleyebilir nasıl?

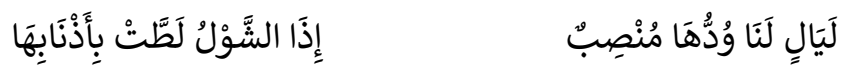

Tutkusunun bizi yorgun düşürdüğü uzun geceler. Yavrusunu doğurduktan yedi ay sonra sütten kesilen devenin kuyruğuyla memelerini gizlemeye çalıştığı o

\footnotetext{
${ }^{61}$ Kays b. el-Hatîm, Dîvân, 42.

62 Beyitte yer alan إذا اصطحبت أربعا ifadesi dört kadeh içtiğimde anlamındadır. Bkz. el-Bekrî Ebû 'Ubeyd, Faslu'l-maḳāl fí şerhịi Kitâbi'l- emsâl, thk. İhsân 'Abbâs ve 'Abdulmecîd 'Âbidîn (Beyrut: Dâru'l-Emâne, 1971), 346.

63 Beyitte yer alan خط مئزري ifadesi elbisemin eteğini böbürlenerek yerlerde sürürüm anlamındadır. Bkz. el-Bekrî, Faslu'l-makāàl fî şerhịi Kitâbi'l- emsâl, 346.

64 Kays b. el-Hatîm, Dîvân, 80.

65 Kays b. el-Hatîm, Dîvân, 134.
} 
geceler.

Beyitlerde şair alışılagelenin aksine âşık olması gerekirken maşuk rolünü oynamaktadır. Kuşkusuz şairin farklı sevgililerle benzer deneyimleri tekrarlıyor olması güzel ve alımlı kızlara olan zaafına işaret etmektedir. Şair Kenûdâ adındaki eski sevgiliyi de hatırlamakta ve adeta her çiçekten bal almak isteyen arı misali fizikî yapısıyla farklı deneyimlere yelken açtığına işaret etmektedir. Şair bu bağlamda şöyle demektedir: ${ }^{66}$

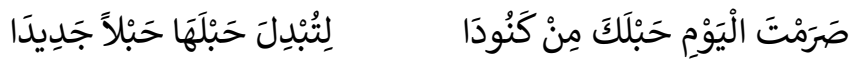

(Behey Kays!) Bugün aşkımıza nankörlük eden (dilber) Kenûdâ ile bağını kopardın. Bir başka (dilberle gönül eğlendirecek) yeni bir bağla değiştirmek için

$$
\text { مِنَ اللَّلئِ إِذَا يَمْشِينَ هَوْناً }
$$

Yürürken rengârenk elbiseler ve hırkalar içerisinde salınan dilberler arasından.

Yapılan izahlardan da anlaşılacağı üzere şair fizikî yapısını, genç kızları aşk tuzağına düşürmesini, içki kullanmak gibi dönemin genç delikanlılarına has eğilimleri ve geçmişte yaşadığı aşk deneyimlerini beyitlere yansıtmaktadır.

\section{1. 4. Erdem}

Câhiliye devrinde şairler, yumuşak başı olma, bilgelik, adalet, sır saklama, komşu haklarını gözetme ve emaneti koruma gibi erdemlerle övünmüşlerdir. ${ }^{67}$ Kays b. el-Hatîm'e ait günümüze ulaşan şiir metinlerinde de benzer değerlerle övünülen beyitlere rastlanmaktadır. Söz gelimi şair halkının çıkarlarını korumak uğruna sabırla zorluklara tahammül ettiğini dile getirdiği beyitlerde yumuşak başı olmakla övünmekte ve şöyle demektedir: ${ }^{68}$

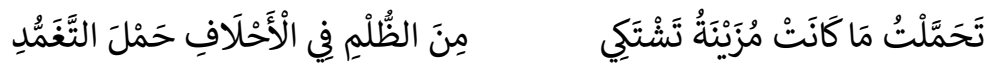

(Kabîlelerle yapılan) anlaşmalar sonucunda Muzeyne kabîlesinin dert ettiği haksızlıklar karşısında (anlaşmaları çiğnememek adına) pek fazla sabrettim.

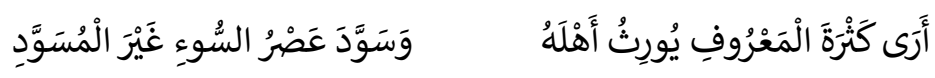

Görüyorum ki çokça iyilik yapmak, bu hasleti sahiplerinde irsîleştirmekte (ve kuşaktan kuşağa aktarmalarını sağlamakta.) Kötülükle yoğrulmak ise dürüst kimsenin itibarını lekelemektedir.

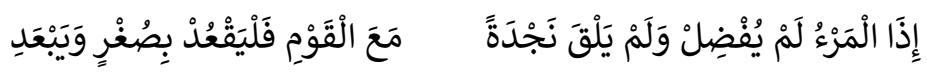

Kişi (başkalarına) iyilikte bulunmamış ve toplulukla birlikte meşakkate katlanmamış ise bırak da zillet içerisinde otursun ve (saygın bir hayat yaşamaktan) uzakta dursun.

Şaire göre yumuşak başı olmak ve zorluklar karşısında sabretmek sınırsız değildir. Şair, düşmanın haddi aşması ve savaşmaktan başka alternatif bırakmaması durumunda cesaretle düşman üzerine gitmekten geri

66 Kays b. el-Hatîm, Dîvân, 145-146.

67 el-Kuraşî, Cemheretu eş'âri'l-'Arab, 2/631-632.

68 Kays b. el-Hatîm, Dîvân, 128. 
durmamaktadır. Hâtıb Günü ${ }^{69}$ münasebetiyle söylediği beyitlerde bu duruma işaret etmekte ve şöyle demektedir: ${ }^{70}$

$$
\text { دَعَوْتُ بَنِي عَوْفِ لِحَقْنِ دِمَائيْهِم: فَلَمَّا أَبَوْا سَامَحْتُ فِي حَرْبِ حَاطِبِ }
$$

'Avf oğullarını' akan kanları durdurmaya davet ettim. Davetimi onlar reddedince ben de Hâtıb savaşına giriştim.

$$
\text { وَكُنْتُ امْرَاً لَا أَبْعَثُ الْحَرْبَ ظَالِماً }
$$

Haksızlık yaparak savaş çıkmasına meydan vermeyen (yumuşak başı) bir kimse idim. Ama onlar (bunu) reddedince her bir yandan savaşın fitilini alevlendirdim.

Şair hayatta çeşitli tecrübeler edinmiş hikmet ehli bilge bir şahsiyet olmakla da övünmektedir. Şaire göre erdem sahibi kimse bâtıl karşısında her zaman haktan yana olmalı ve yanlışa tevessül etmemelidir. Şair bu ve benzer düşünceleri teoride kendi hayatına uyarlamaktadır. Söz gelimi cömertliğin israf olduğunu öne süren bazı kimseler tarafından kendisine yöneltilen eleştirilere kulak asmamakta ve beyitlerde şöyle demektedir: ${ }^{72}$

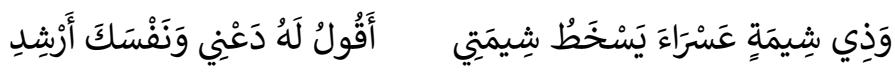

Kaba mizaç sahibi kimse mizacıma (takmış da) hiddetlenmekte. Ben de ona "Benimle uğraşmayı bırak ve nasihatini kendine sakla!" diyorum.

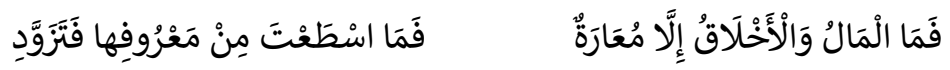

Zira mal da ahlâk da ödünç alınan borçtan öte bir şey değildir. Dolayısıyla bunların itibar gören türünden gücün nispetinde azık edin.

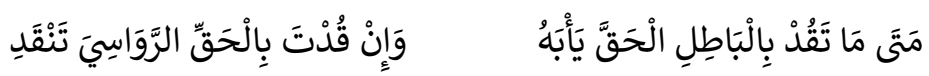

Ne zaman hak olanı bâtılla yönetmeye kalkışsan (hak) buna direnir. (Hâlbuki) hak ile yüksek dağları yönetsen (sana) boyun eğer.

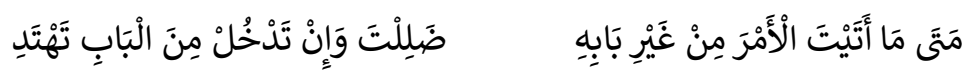

Ne zaman (bir) işe kapısı dışında (başka yollara tevessül ederek) gelirsen

\footnotetext{
69 İslâm'dan hemen önce Evs ve Hazrec kabîleleri arasında yaşanan Hâtıb Günü, Evs kabîlesine lider olan Hâtıb b. Kays'a (ö. ?/?) nispetle yapılan savaşın adıdır. Hâtıb b. Kays, Sa'lebe b. Sa'd oğullarından bir şahsı himayesine alır. Söz konusu şahıs bir gün Kaynuka' oğulları pazarına uğrar. Bu sırada el-Hâris b. el-Hazrec oğullarına mensup bir şahıs Yahudilerden bir kimse ayartır ve himaye altındaki şahısın poposuna vurdurur. Hâtıb b. Kays'ın himayesindeki şahıs "Popomdan vuruldum! Yazıklar olsun! Nerede kaldı himaye altında bulunuyor olmam!" diye bağırır. Konuğunun bu şekilde aşağılanmasına sinirlenen Hâtıb, orada Yahudiyi ve ayartıcısı olan Hazrecliyi öldürür. Durumdan haberdar edilen Hâris oğulları aşîreti de harekete geçer ve Hâtıb'ı öldürür. Böylece Evs ve Hazrec kabîleleri arasında savaş patlak verir. İki kabîle Medine dışında er-Radm b. Buthân adındaki vadide karşı karşıya gelirler. Zorlu çatışmaların yaşandığı Hâtıb Günü akşamında Hazrecliler, Evs kabîlesi karşısında zafer ilan ederler. Geniş bilgi için bkz: İbn el-Esîr, el-Cezerî, Ebu'lHasen 'Ali b. Ebî'l-Kerem, Muhammed b. Muhammed b. 'Abdulkerîm, b. 'Abdu'I-Vâhid eş-Şeybânî, el-Kâmil fít-târîh, thk. Ebu'I-Fidâ 'Abdullah el-Kâdî (Beyrut: Dâru'I-Kutubi'I-'Illmiyye, 2003), 1/531.

70 Kays b. el-Hatîm, Dîvân, 80-81.

${ }^{71}$ Beyitte yer alan 'Avf oğulları ile Hazrec kabîlesi kastedilmektedir. Bkz. Kays b. el-Hatîm, Dîvân, 81.

72 Kays b. el-Hatîm, Dîvân, 129-130.
} 
sapıtırsın. (Ama) kapıdan girersen doğruya kavuşursun.

Şair, düşmanca tavır sergilenmediği sürece kimseye haksızlık yapmamaktadır. Yine şair savaş gibi felâketlerin ortaya çıkması durumunda nasıı hareket edileceği yolunda yeterli beceriye sahiptir. Şair bu durumla övünmekte ve beyitlerde şöyle demektedir: ${ }^{73}$

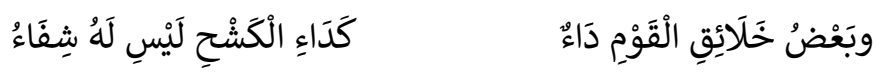

Bazı toplulukların huyları tıpkı zatülcenp illeti gibi tedavisi bulunmayan bir hastalıktır.

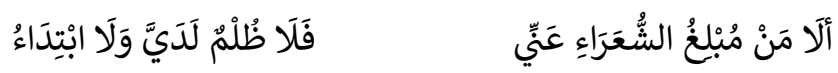

Dinleyin! Şunu kim ulaştırır şairlere benden: Kimseye ne haksızlık ederim ne de (kimsenin başını belaya sokacak sorunları) tetikleyen olurum.

$$
\text { وَلَسْتُ بِعَابِطِ الْأَكَفَّاءِ ظُلْمَاً }
$$

İsini bilen kimseleri haksız yere değerden düşürmem. Felâketler karşısında (sorunları çözebilecek) kabiliyetim de söz konusudur.

Şair sır saklama konusunda da ağzı sıkıdır. Dostları tarafından kendisine sır olarak söylenenleri veya mensubu bulunduğu aşîretin gizli kalması gereken sırlarını korumakla övünmekte ve şöyle demektedir: ${ }^{74}$

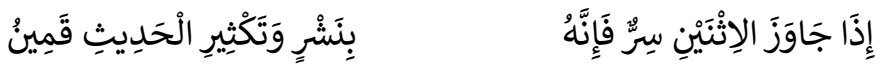

Eğer sır iki kişiyi aşmış ise yayılmayı ve dillere sakız olmayı hak eder.

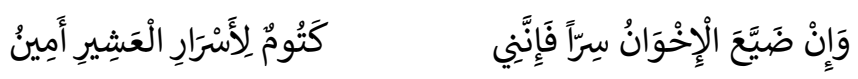

Dostlar (aralarındaki) bir sırrı zayi etmiş olsalar bile benim ağzım aşîretin sırlarını saklama konusunda pek sıkıdır ve (bu hususta etrafa) güven veren emin bir kimseyimdir.

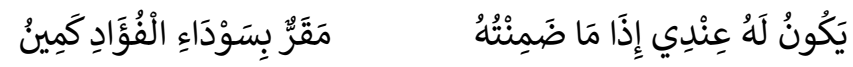

Şayet sır saklamayı taahhüt etmiş isem kalbimin tam ortasında o sırrın karar kılacağı gizli bir yeri vardır kesin.

Şair komşu haklarına da riayet etmektedir. Zira şair iffet sahibidir ve gözünü haramdan sakındırmaktadır. Komşunun mallarını gıyabında korumakta ve ırzına halel getirtmemektedir. Bu sebeple komşusu evinden ve yurdundan uzaklaşırken gözü arkada kalmamaktadır. Şair beyitlerde bu durumla da övünmekte ve şöyle demektedir: ${ }^{75}$

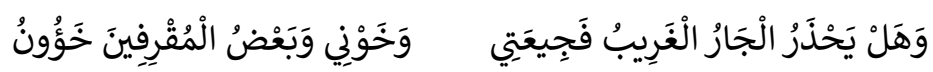

(Ey Sevgili! Gıyabımda beni sor soruştur) garip komşu (benden yana başına gelebilecek olası) faciadan sakınıyor mu?

$$
\text { وَمَا لَمَعَتْ عَيْيني لِغِرَّة جَارَةٍ }
$$

73 Kays b. el-Hatîm, Dîvân, 154-155.

74 Kays b. el-Hatîm, Dîvân, 163-164.

75 Kays b. el-Hatîm, Dîvân,165. 
Gözüm komşu kadına ne gaflet anında ilişti ne de veda anında beni zemmederek gözden kayboldu.

Yapılan izahlardan da anlaşılacağı üzere şaire ait günümüze ulaşan şiirlerde cesaret, cömertlik, fizikî yapı ve erdem gibi kişisel övünmelerin yansımalarına rastlanmaktadır. Şair bunu yaparken kabile kültüründen ve yaşadığı deneyimlerden edindiği hayat tecrübesini de beyitlere yansıtmaktadır. Söz gelimi şaire göre gönlü zengin kimse her daim zengin iken tamahkâr kimse ömür boyu bedbahttır. Yine şaire göre mal ve ahlâk, ödünç alınacak borçtan öte bir şey değildir. Bu bakımdan cimri kimsede hayır yoktur. Yine şaire göre sır iki kişiyi aşmış ise sır olmaktan çıkar ve dillere destan olur. Kuşkusuz bu türden yaklaşımların dönemin kültürel ve zihinsel yapıları hakkında ip uçları verdiği muhakkaktır.

Illgili şiir metinlerinde şairin mensubu bulunduğu Evs kabilesiyle ve Evs kabilesinin alt kolu olan Nebît boyuyla da övündüğü beyitlere rastlanmaktadır.

\section{2. Kabîleyle Övünme}

Câhiliye devrinde kabîleye aidiyet güçlüdür. Zira kabîleler arasında sıkça yaşanan çatışmalar ve az sayıda su kaynaklarını ele geçirmek amacıyla ateşlenen rekabet savaşları kabîle bireyleri arasında dayanışmayı zorunlu kılmaktadır. Kabîle bireyleri ortak menfaatleri korumak amacıyla maddî ve manevî her türden silahı kullanmak durumundadırlar. Düşman kabîlenin maneviyatını çökertmek amacıyla kullanılan en güçlü silah hamaset şiirleridir. Şairler aynı zamanda kabîle bireylerini düşmana karşı savaşa teşvik etmek amacıyla asabiyet fitilini de ateşlemektedirler. Şairler bunu yaparken bireyler arasındaki dayanışma ruhunu güçlendirecek ortak paydalarla beyitlerde övünmektedirler. ${ }^{76}$

Kays b. el-Hatîm'e ait şiir metinlerinde de aşiretle övünme temalarına rastlanmaktadır. Söz konusu temaları soy bağı, aşîretin gücü, parlak geçmişi ve itibarı olmak üzere dört alt başlıkta incelemek mümkündür.

\section{2. 1. Soy Bağı}

Kays b. el-Hatîm, Evs kabîlesinin alt kolu olan Nebît boyuna mensuptur. Şair çoğu defa Nebît boyuyla olan soy bağıyla övünmekte ve Nebît boyunu yüceltmektedir. Şaire göre Nebît boyu benzersiz olup izzet ve şeref sahibidir. Bu sebeple Nebît boyunun her bireyi övülmeyi hak etmektedir. Şair bu bağlamda şöyle demektedir: ${ }^{77}$

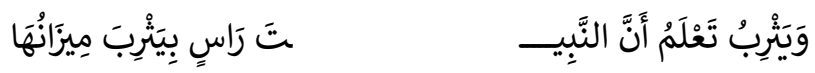

Yesrib (halkı şunu iyi) bilir: Nebît, Yesrib'de köklü bir ağırlığa sahiptir.

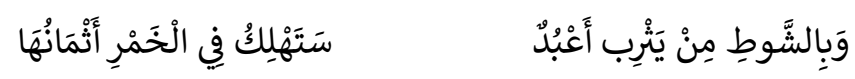

Yesrib'in eş-Şavt ${ }^{78}$ (isimli bostanında) içkiye (harcama yapmak için) değerden düşecek nice köleler vardır.

\footnotetext{
76 Tuleymât Gâzî ve el-Aşkar, 'İrfân, el-Edebu'l-câhilî, 147-148.

77 Kays b. el-Hatîm, Dîvân, 72-74.

78 Beyitte yer alan الشوط, Medîne'de etrafı surlarla çevrili bir bostanın adıdır. Bkz. Hamevî, Mu'cemu'l-buldân, 3/ 372.
} 


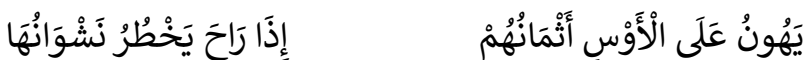

(Şöyle ki) Evs halkı sarhoşluk etkisini göstermeye başlayınca (kölelerin kaça satılacaklarını) umursamazlar.

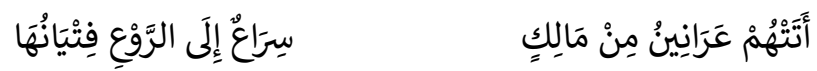

Mâlik'in ${ }^{79}$ soyuna mensup delikanlılar arasından savaşın dehşetine (korkusuzca) firlayacak asil kimseler düşmanlarla (vuruşmaya) geldiler.

$$
\text { وَقَقَدْ عَلِمُوا أَنَّ مَا فَلَهُهْ }
$$

Ve (nihayet) düşmanlar (şunu iyice) anladılar: Hasımları darmadağın perişan kılan Nebit'in ileri gelen asilleri ve demirden (yapılmış keskin silahlarıdır.)

Görüleceği üzere beyitlerde Nebît boyuna mensup bireyler gözü pek cesur kimseler olup benzerleri yoktur. Yine şair beyitlerde Nebît boyuna mensup bireylerin el-Ağarr oğullarının ileri gelenlerini cesurca öldürmüş olmalarıyla da övünmekte ve şöyle demektedir: ${ }^{80}$

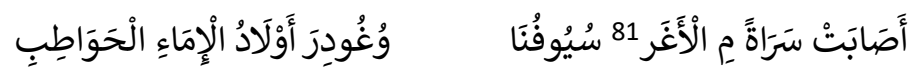

Kılıçlarımız (özellikle) el-Ağarr ${ }^{22}$ (soyundan gelen Hazrecli) liderleri hedef aldı. Odun toplayan cariyelerin evlatlarına (ise) dokunulmadı.

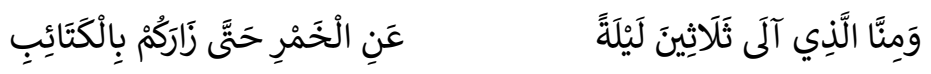

Birliklerin eşliğinde sizi yurdunuzda ziyaret edinceye (ve size karşı zafer kazanıncaya) kadar otuz (gün ve) gece içkiden uzak durmaya yemin eden de bizdendir. ${ }^{83}$

Şair Evs kabîlesiyle olan soy bağıyla da övünmekte ve Evs kabîlesinin kahramanlıklarını beyitlere yansıtmaktadır. Bunu yaparken düşman kabîlelerin Evs kabîlesi karşısında uğradıkları yenilgilere de değinmektedir. Şair Fezâ Günü ${ }^{84}$ münasebetiyle dile getirdiği beyitlerde şöyle demektedir: ${ }^{85}$

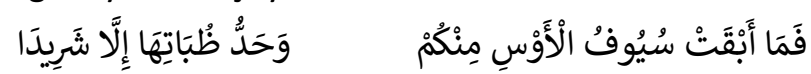

Evs'in kılıçları ve (kılıçların) keskin tarafları sizden kimseyi sağ bırakmadı.

79 Beyitte yer alan مالك, en-Nebît'in babası Mâlik b. el-Evs b. el-Hârise'dir. Bkz. Kays b. el-Hatîm, Dîvân, 73

80 Kays b. el-Hatîm, Dîvân, 91.

81 Beyitte yer alan من الأغر if şeklindedir. Şiirde vezni korumak amacıyla نون الأغر ifadesinin aslı harfinin düşürülmesi sıkça rastlanan bir olgudur. Söz gelimi bkz. es-Sakkâ, Mustafâ, Muhtâru'şşi'ri'l-câhilî, (Beyrut. Dâru'l-Fikr, 2014), 2/394.

82 Beyitte yer alan الأغر, Mâlik el-Ağarr b. Sa'lebe b. Ka'b b. el-Hazrec'dir. Bkz. Kuraşî, Cemheretu eș'âri'l-'Arab, 2/652.

83 Beyitte yemin ettiği yolunda sözü edilen şahıs, Bu'âs günü Evs kabîlesinin lideri olan Hudayr b. Simâkdır. Hudayr b. Simâk, Abdullah b. Ubeyy b. Selûl'e (ö. 9/630) ait mülk etrafındaki suru yerle bir edinceye kadar içki kullanmamaya yemin etmiştir. Bkz. Kuraşî, Cemheretu eş'âri'l-'Arab, 2/652.

${ }^{84}$ Fezâ Günü, İslâm'dan önce Evs ve Hazrec kabîleleri arasında yaşanan savaşlardan birinin adıdır. Fezâ Günü, iki taraf arasında şiddetli çarpışmalar meydana gelmiş ve gece karanlığı bastıııncaya kadar sürmüştür. Savaş, Evs kabîlesinin Hazrec kabîlesi karşısında yenilmesiyle son bulmuştur. Bk. el-Kuraşî, Cemheretu eş'âri'l-'Arab, 2/ 629.

85 Kays b. el-Hatîm, Dîvân, 149. 
(Olup biteni anlayamadan) kaçan(lar) dışında.

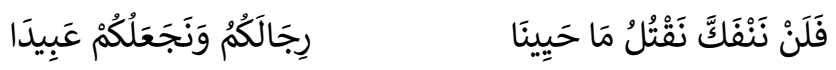

Hayatta kaldığımız süre adamlarınızı öldüreceğiz ve sizi köleler(imiz) yapacağız.

Şair atalarıyla da övünmekte ve atalardan asaleti miras aldığını öne sürmektedir. ${ }^{86}$

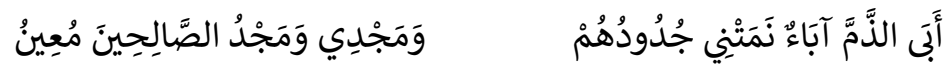

Beni atalarından (miras gelen asaletin) yetiştirdiği büyükler yerilmeyi reddettiler. Dürüstlerin asaletine dayanaktır benim asaletim.

Verilen örneklerden de anlaşılacağı üzere şair mensubu bulunduğu Nebît boyunu yüceltmekte ve Nebît boyunun izzeti ve şerefiyle övünmektedir. Şair bunu yaparken Fezâ Günü'nde olduğu üzere düşman kabîlelerin Evs kabîlesi karşısında uğradıkları yenilgilere de değinmektedir.

\section{2. 2. Kabîlenin Gücü}

Şairin soyuyla övünüyor olması mensubu bulunduğu Evs kabîlesinin gücüyle irtibatlıdır. Nitekim şair, savaş sanatında oldukça mahir bir kabîlenin mensubudur. Şair, Evs kabilesinin sözcülüğünü yapmakta ve sahip olduğu güçle övünmektedir. Bu'âs Günü ${ }^{87}$ münasebetiyle dile getirdiği beyitler bu duruma örnek gösterilecek mahiyettedir: 88

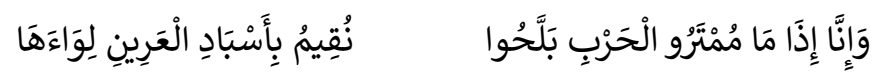

Savaşı kazanma arzusunda olanlar yorgun düştüklerinde biz arenadaki aslanların (ortasına zafer) sancağı dikeriz.

$$
\text { وَنْلُحِقُهَا مَبْسُورَةً ضَرْزَنَيَّةً }
$$

Ardından asice darbelerle burunları yerde sürtünceye kadar kılıçlarımızla onları kovaları.

\footnotetext{
${ }^{86}$ Kays b. el-Hatîm, Dîvân, 166.

${ }^{87}$ Bu'âs Günü, İslâm'dan hemen önce Evs ve Hazrec kabîleleri arasında meydana gelen son savaşın adıdır. Medine' de yaşayan Yahudiler, Hazreclilere karşı Evs kabîlesiyle ittifak yaparlar. Bu dumdan haberdar edilen Hazrecliler, Mu'abbis ve Mudarrıs Günü Yahudilerden rehin aldıkları herkesi kılıçtan geçirirler. Bunun üzerine Evs, Kurayza ve en-Nadîr oğulları harekete geçerler ve Hazrec kabîlesine karşı birleşerek savaş kararı alırlar. Civar bölgelerde yaşayan Yahudi kabîleler de Evs ve müttefiklerine katılırlar. Hazrec kabîlesi ise, Eşca've Cuheyne kabîleleriyle ittifak yapmak zorunda kalır. Hazrec ve müttefikleri kırk gün hazırlık yaptıktan sonra iki ordu Kurayza kabîlesinin yerleşim birimlerinden biri olan 'Bu'âs'ta karşı karşıya gelirler. Zorlu geçen çarpışmaların ardından Evs ve müttefikleri zafer ilan ederler. Bu sırada Evsli bir şahıs ayağa kalkar ve Evslilere hitaben bir konuşma yapar. Evsli şahıs konuşmasında Evslilere Hazrecli kardeşlerini öldürmemeleri tavsiyesinde bulunur. Konuşmacı, Evslilerle birlikte yan yana yaşamanın tilki kurnazlığındaki Yahudilerle birlikte yaşamaktan daha isabetli olacağını söyler. Konuşmayı yerinde bulan Evsliler Hazreclileri serbest bırakırlar ve mallarına dokunmazlar. Ne var ki Kurayza ve en-Nadîr Yahudileri, Hazreclilere ait malları talan ederler. Geniş bilgi için bkz. İbn el-Esîr, el-Kâmil fítt-târîh, 1/538.

88 Kays b. el-Hatîm, Dîvân, 50-51
} 


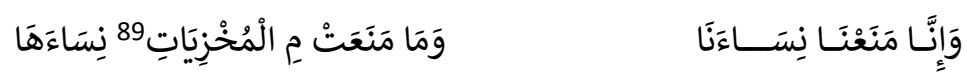

Biz Bu'âs Günü hanımlarımızı koruduk. (Ama) onlar namuslarını lekeleyecek zilletlerden kendi hanımlarını koruyamadılar.

Şair Rubey' Günü ${ }^{90}$ münasebetiyle söylediği beyitlerde yine Evs kabîlesinin gücüyle övünmekte ve şöyle demektedir: ${ }^{91}$

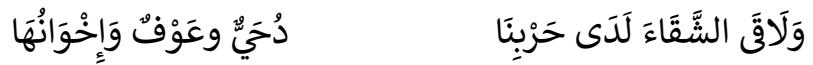

Savaşımız esnasında Duhayy, 'Avf ve destekçileri' (çetin direnişle) karşılaştılar da perişan oldular.

$$
\text { رَدَدْنَا الْكَتِيَبَة مَفْلُولَةً }
$$

(Böylece) aptal ve beceriksiz birliği darmadağın geri püskürttük.

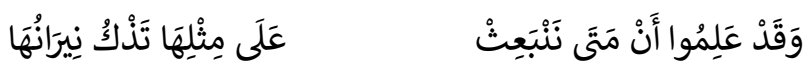

(Sonunda) şunu (iyice) öğrendiler: Ne zaman benzer savaşlara zorlanarak kışkırtılırsak (bir başka) alevlenir savaşların ateşleri.

Şair Hâtıb savaşı münasebetiyle söylediği beyitlerde de yine Evs kabîlesinin gücüyle övünmekte ve şöyle demektedir: ${ }^{93}$

$$
\text { صَبَحْنَا بِهَا الْآَطامَ حَولَ مُزَاحِمِ }
$$

Sabah vaktine girdiğimizde savaşı ön kısımları yıldızlar gibi parıldayan miğferlerimizle Muzâhim (adındaki kalenin) etrafındaki kalelerde sürdürdük.

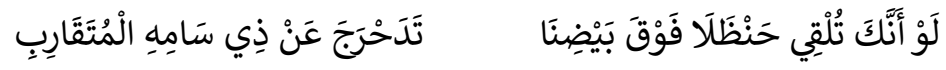

(Savaşşılarımız o kadar kalabalık ve yan yanadır ki) miğferlerimizin üzerine ebucehil karpuzu atmış olsan birbirine yakın altın kaplamalı çizgilerinden yuvarlanır da (yere düşmezdi.)

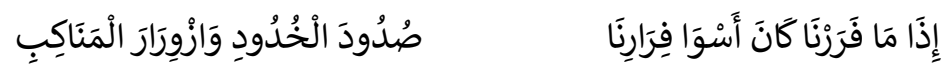

(Biz asla savaştan kaçmayız.) Kaçmış isek eğer en kötü ihtimalle sadece yanaklarımızı darbelerden uzak tutmak ve omuzlarımızı sağa sola hareket ettirmek şeklinde olmuştur kaçısıımız.

89 Beyitte yer alan م المخزيات ifadesinin aslı şeklindedir. Bkz. es-Sakkâ, Mustafâ, Muhtâru'ş-şi'ri'I-câhilî, 2/394.

90 Rubey' Günü, Evs ve Hazrec kabîleleri arasında meydana gelen Hâtıb savaşının yaşandığı günlerden biridir. Rubey' Günü, Evs kabîlesi Hazrec kabîlesi karşısında ağır yenilgi alır. Geçmişte yaşanan savaşlarda yenilen taraf evlerine çekilmekte böylece savaş sona ermektedir. Rubey' Günü Evs kabîlesi mensupları evlerine çekilmişler ve Hazreclilerden savaşı durdurmalarını istemişlerdir. Ne var ki Hazrecliler bu talebi reddetmişler ve Evslileri evlerinde dahi vurmaya kalkışmışlardır. Bu durum karşısında Evs mensupları hanımlarını korumak amacıyla surlarla çevrili kalelere yerleştirirler. Bunu gören Hazrecliler savaşı sonlandırma kararı alırlar. Bkz. ỉbn el-Esîr, el-Kâmil fít târîh, 1/532; Kassâb, Velîd, Dîvânu 'Abdillâh b. Ravâha dirâse fí sîratih ve şi'rih, (Riyad: Daru'I'Ulûm, 1982), 52.

91 Kays b. el-Hatîm, Dîvân, 71-72.

92 Beyitte yer alan Duhayy, 'Avf ve destekçileri ile Hazrec kabîlesine mensup Mâlik b. En-Neccâr'ın amca çocukları kasdedilmektedir. Bkz. Kays b. el-Hatîm, Dîvân, 71.

${ }^{93}$ Kays b. el-Hatîm, Dîvân, 86-88. 


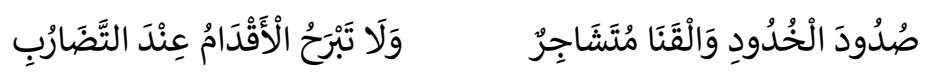

Mızrakların vuruştuğu sırada yanaklarımızı darbelerden uzak tutmak şeklinde olmuştur kaçışımız. Ayaklar (ise) vuruşma anında hala yerinde sabit kalmıştır.

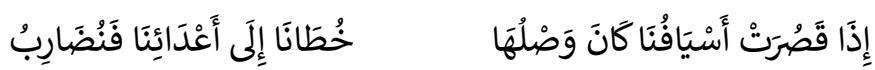

Kılıçlarımız düşmanlarımıza uzanamayacak (kadar uzakta ise koşar) adımlarımızla ulaştııırız da kılıçtan geçiririz onları.

Beyitlerde Evs kabîlesinin gücüyle övünülürken "biz" kipinin sıkça kullanılıyor olması dikkat çekmektedir. Şairin "biz" kipi kullanmak suretiyle bireyler arasında kabîleye aidiyet ruhu aşılamayı ve gelecek kuşaklara bu bağlamda mesaj iletmeyi amaçladığı açıktır.

\section{2. 3. Parlak Geçmiş}

Şair mensubu bulunduğu Evs kabîlesiyle övünürken kabîlenin başarılarla dolu parlak geçmişini de sıkça dile getirmektedir. Söz gelimi Bu'âs Günü Kavrâ adıyla bilinen yerde kabîle bireylerinin Abdullah b. Ubeyy b. Selûl (ö. 9/631) ve beraberindekileri öldürdükten sonra cesetlerini yırtıcı hayvanlara yem olarak bıraktıklarını dile getirmekte ve şöyle demektedir: ${ }^{94}$

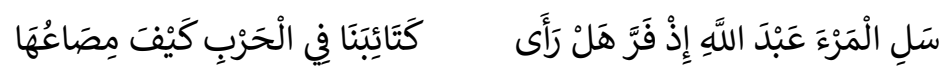

Abdullah $^{95}$ (savaş meydanından) kaçarken birliklerimizin savaştaki vuruşmasını görmüş mü? Bu (hadiseyi bilen) kişiye Abdullah'ı sor (hele.)

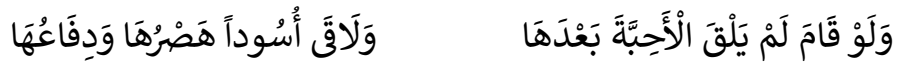

O hadiseden sonra (Abdullah canlanıp) ayağa kalksa (bile) dostlarını bulamazdı. (Aksine) aynı anda çevik ve savunma (kabiliyetine sahip) aslanlar bulurdu karşısında.

$$
\text { وَنَحْنُ هَزَمْنَا جَمْعَكُمْ بِكَتِبَبةٍ }
$$

Biz Kavrấnın ovasıyla tepesiyle önünde dar geldiği bir birlikle birliğinizi bozguna uğrattık.

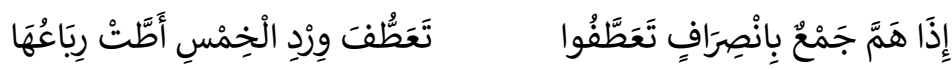

(Düşmanlardan bozguna uğramış) bir birlik (meydandan) ayrılmaya yeltenmiş ise bizimkiler üç gün susuz bırakıldıktan sonra dördüncü günde su kaynağına salıverilen aynı zamanda yavrularının da özlemle bekleyiş içerisinde olduğu develerin suya akın etmesi gibi (düşmana saldırırlar da) geri adım atmazlar (asla.)

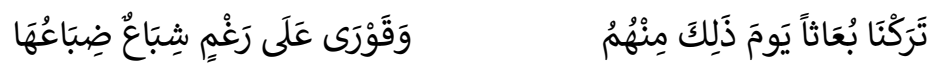

O gün, düssmanlardan artakalan cesetlere Kavrâ'nın yırtıcı hayvanları doymuş halde Bu'âs bölgesinden ayrıldık biz.

\footnotetext{
${ }^{94}$ Kays b. el-Hatîm, Dîvân, 142-144.

95 Beyitte sözü edilen Abdullah, Bu'âs Günü savaş meydanından kaçan Abdullah b. Ubeyy b. Selûl'dur. Bkz. İbn el-Esîr, el-Kâmil fi't-târîh, 1/538; Kays b. el-Hatîm, Dîvân, 142.
} 
Yine Bu'âs Günü kabîle mensuplarından her biri kılıcını kınından tertemiz olarak çıkarmış ve kahramanca düşmanla çarpışmıştır. Çarpışmanın sonunda kılıçlar al kana boyanmış ve körelmiştir. Şair bu bağlamda şöyle demektedir: ${ }^{96}$

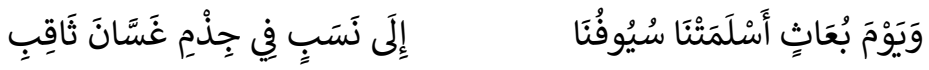

Bu'âs Günü kılıçlarımız bizi Gassân'ın asaletindeki parlak bir nesebe ulaştırdı.

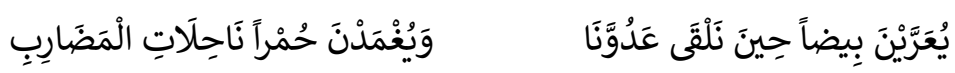

Kılıçlarımız düşmanımızla karşı karşıya geldiğimizde bembeyazdırlar. Kınlara geri konulur iken al kana boyanmış ve darbe alan bölgeleri körelmiştir.

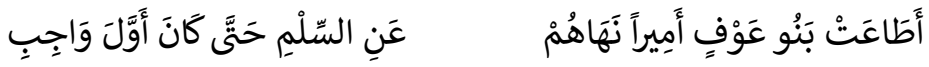

'Avf oğulları kendilerine barışı yasaklayan bir lidere uydular da ilk helak olan kimse (uydukları lider) oldu. ${ }^{97}$

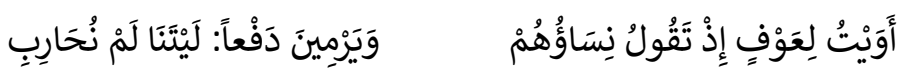

Kadınları kendilerini savunmak amacıyla (surların üzerinden) bize silah fırlatırlarken "Keşke savaşmayaydık" dedikleri vakitte 'Avf oğullarına acıdım.

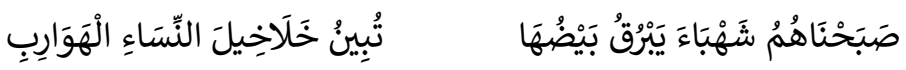

Biz miğferlerden yansıyan parıltıların kaçışmakta olan kadınların halhallarını aydınlattığı birliklerle düşmanın yurduna girdik sabahın köründe.

Şair bazı vakitler geçmişte yaşanan savaşlarda hasım kabîlelere karşı elde ettikleri zaferleri zikretmekle yetinmektedir. Söz gelimi şair Feza Günü ‘Avf oğulları ve destekçileri karşısında kaydettikleri zafere gönderme yapmakta ve şöyle demektedir: $: 88$

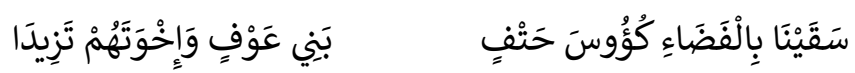

(Yesrib'in) Fezâ (isimli bölgesinde) 'Avf oğullarına ve destekçileri Tezîd ${ }^{99}$ (oğullarına) ölüm badeleri içirdik.

$$
\text { لَفِينَاهُمْ بِكُلِّ أَخِي حُرُوبٍ }
$$

Peşi sıra teçhizatlı birlik yöneten her bir savaş̧̧ıla karşı karşıya geldik onlarla.

Şair, Mekke'nin er-Redm isimli bölgesinde geçmişte yaşanmış bir savaşta Hazreclileri ve Hazreclilerin müttefiklerini nasıl bozguna uğrattıklarını da düşmanlara mesaj yoluyla hatırlatmakta ve şunları söylemektedir: ${ }^{100}$

$$
\text { أَلَا أَبْلِغَا ذَا الْخَزْرَجِيَّ رِسَالَةً }
$$

Dinleyin! Bu Hazrecliye benden bir mesaj ulaştırın! (Dile getirdiğim

\footnotetext{
96 Kays b. el-Hatîm, Dîvân, 89-91.

97 Beyitte sözü edilen lider, 'Avf oğullarının lideri 'Amr b. en-Nu'mân el-Beyâdî'dir. Bkz. İsfâhânî, Kitâbu'l-ağânî, 17/93.

98 Kays b. el-Hatîm, Dîvân, 145.

99 Beyitte yer alan تزيد ile Seleme b. 'Ali b. Tezîd oğulları kasdedilmektedir. Bkz. Kays b. el-Hatîm, Dîvân, 145.

100 Kays b. el-Hatîm, Dîvân, 216,-217.
} 
hususlarda) iddialarımın çürütülmeyeceği gerçekleri yansıtan bir mesaj.

$$
\text { فَإِنَّا تَرَكْنَاكُمْ لَدَى الرَّدْمِ غُدْوَةً }
$$

Şöyle ki er-Redm'de bir sabah vakti sizi iki grup halinde öldürülmüş ve kovalanmıs olarak bıraktık

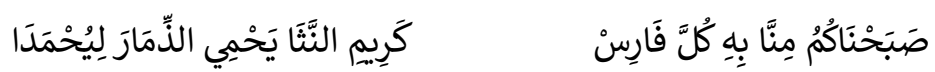

Yurdunun ve ırzının hamisi aynı zamanda övgüye layık olabilmek için (var gücüyle dövüşebilen) saygın her bir süvariyle sabahın köründe size saldırdık.

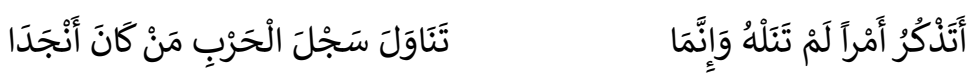

Hatırlar mısın elde edemediğin (şu) işi? Hani sen değil de himmeti yüksek kimse savaşın galibiyetini elde etmişti.

Yapılan izahlardan da anlaşılacağı üzere şair bilfiil yaşadığı veya kabîlenin parlak geçmişiyle ilgili bilgileri beyitlere yansıtmakta ve bunlarla övünmektedir.

\section{2. 4. İtibar}

Güç, asalet ve parlak geçmiş gibi özelliklerin kabîleye itibar kazandırması ve şairin de bunlarla övünmesi beklenecek bir durumdur. Kays b. el-Hatîm de söz konusu özellikleri yansıtan anlamları beyitlere yansıtmakta ve bunlarla sıkça övünmektedir. Söz gelimi kabîlesinin yeryüzüne hâkim olduğunu öne sürmekte ve şöyle demektedir: ${ }^{101}$

$$
\text { إِنَّ الْفَضَاءَ لَنَا فَلَا تَمْشُوا بِهِ }
$$

Doğrusu şu (engin) uzay boşluğu (altında kalan her yer) bizimdir. O halde ne eteklerde ne de yükseklerde yürümeyin asla.

Şaire göre Evs kabîlesi yeryüzünde her yere hâkimdir. İnsanların bir yerden başka bir yere intikal etme imkânları ancak Evs'in izniyle mümkündür. Yine şaire göre düşmanlar Evs karşısında savunmasızdırlar ve kurtulmak için yegâne şansları kaçmalarıdır. Şair bu durumla övünmekte ve beyitlerde şöye demektedir: ${ }^{102}$

$$
\text { فَلَمْ تَمَنَعُوا مِنَّا مَكَانَاً نُرِيدهُ }
$$

Ele geçirmeyi istediğimiz size ait herhangi bir yeri (gizlenmiş olduğunuz) odaların duvarları müstesna karşımızda savunmadınız.

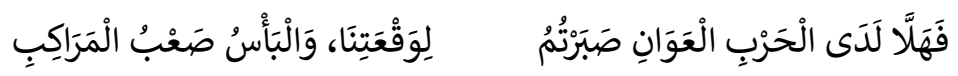

Art arda kanlı çarpışmalara sahne olan ve büyük cesaret gerektiren o zorlu savaşta uğrattığımız bozgun karşısında sabredemediniz değil mi?

Görüleceği üzere Evs kabîlesinin sahip olduğu güç karşısında kimse direnememektedir. Bu sebeple Evs'in diğer kabîleler üzerinde her zaman hâkimiyet sağlamaya muktedir olduğu ve saygınlığı dillerden düşmemektedir. Şair bu bağlamda şöyle demektedir: ${ }^{103}$

\footnotetext{
101 Kays b. el-Hatîm, Dîvân, 61.

102 Kays b. el-Hatîm, Dîvân, 93.

103 Kays b. el-Hatîm, Dîvân, 139.
} 


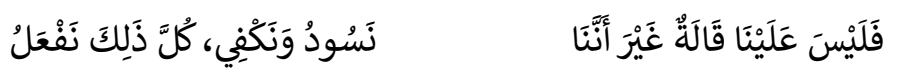

Bizim hakkımızda şu ifade dışında söz yoktur: Biz (dilediğimize) hükmederiz ve dilediğimizi koruruz. Bütün bunları biz yaparız.

Düşman kabîleler zor anlarda savaş meydanlarını arkada bırakarak kaçmakta veya teslim olmakta iken Evs kabîlesi sadece zafere odaklanmatadır. Şair Bu'as Günü münasebetyile söylediği beyitte ${ }^{104}$ şöyle demektedir: ${ }^{105}$

$$
\text { وَ وَيَأْنَ جَمْعُكُمْ إِلَّا فِرَارًاً }
$$

Birliğiniz kaçmaktan başka çarelere gönülsüz (iken) birliğimiz er meydanında öne çıkma dışında bütün seçeneklere karşıdır.

Evs'li savaş̧̧ılara göre itibarsız bir yaşam ölümden beterdir. Bu sebeple gerektiğinde ölüme her an seve seve gitmektedirler. Şair bu durumla övünmekte ve şöyle demektedir: ${ }^{106}$

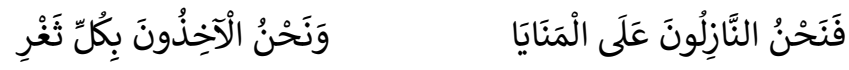

Ölümlerin üzerine konanlar bizleriz. (Yurtlarımızın savunmasında) her boşluğu alanlar (yine) bizleriz.

Yapılan izahlardan da anlaşılacağı üzere Evs kabîlesinin zaferlerle dolu parlak geçmişi ve övgüye değer hasletleri şairi yaşananları kayıt altına almaya sevk etmiştir. Zira şair kabîlenin sözcüsü ve lisân-ı hâlidir. Bu sebeple beyitlerin dile getirildiği genel ortam şairi hem kişisel hem de mensubu bulunduğu Evs kabîlesine ait hasletlerle övünmeye yönlendirmiştir. Şairin gerek şahsında gerekse Evs kabîlesinde var olan hasletlerle övünürken kabîlesini savunma dürtüsüyle hareket ettiği ve duygularında samimi olduğu aşikârdır.

\section{Sonuç}

Şaire ait günümüze ulaşan şiir metinlerinde övünme içerikli beyitler incelenmiş ve çalışmanın sonunda şu sonuçlara varılmıştır:

Evs kabîlesinin sözcüsü konumundaki şair, şiir becerisini savaş halinde oldukları Hazreclilere karşı bir tür psikolojik savaş aracı olarak kullanmaktadır. Şair bunu yaparken fizikî görünümüne ek olarak mensubu bulunduğu Evs kabîlesinden aldığı cömertlik, cesaret ve erdemli olma gibi değerlerle sıkça övünmektedir. Şair aynı zamanda Evs kabîlesiyle olan soy bağı, aşîretin gücü, kabîlenin parlak geçmişi ve itibarı gibi hasletlerle de övünmektedir. Şaire ait şiirlerde övünme içerikli

\footnotetext{
104 Bu'as Günü savaşın ilk anlarında Hazrecliler Evs kabîlesi karşısında üstünlük sağlarlar. Evsliler savaş meydanını terk ederler ve kaçmaya başlarlar. Bu durumu gören Evs'li lider Hudayr el-ketâib el-Eşhelî (ö. ?/?) yenilgiyi içine sindiremez. Elindeki mızrağı bacağına saplar ve Evslilere haykırarak geri dönmeleri ve savaş meydanını terk etmemeleri yolunda çağrıda bulunur. Evsliler geri dönerler ve şiddetli çarpışmalar sonucunda Hazreclilere ağır kayıplar verdirirler. Savaş Evslilerin zaferiyle son bulur. Bkz. el-Cebbûrî, Munzir, Eyyâmu'I-'Arab ve eseruhâ fi'ş-şi'ri'l-Câhilî (Bağdâd: Dâru'şŞuûni's-Sekâfiyye el-'Âmme, ts.), 97.

105 Kays b. el-Hatîm, Dîvân, 149.

106 Kays b. el-Hatîm, Dîvân, 187.
} 
beyitler kişisel ve kabîleyle övünme olmak üzere iki kısma ayrılmaktadır. Şair kendinde var olan özelliklerle övünmeyi mensubu bulunduğu Evs kabîlesini veya Evs kabîlesinin kolu olan Nebît boyunu övme olarak telakki etmektedir. Şair kabîlenin kahramanlıklarla dolu tarihini beyitlerde kayıt altına almak suretiyle gelecek kuşaklara aktarmayı da amaçlamaktadır.

Câhiliye Arap şiirinde kabîleyle övünen ve kabîleye sadık kalan çok sayıda şairin bulunuyor olması dikkate alındığında Kays b. el-Hatîm'in kişisel ve kabîleyle övünme hususunda ilk olmadığı açıktır. Kays b. el-Hatîm'i bu bağlamda ayrıcalıkı kılan şey, kabîlenin hasletlerini ve parlak geçmişini pek fazla dile getiriyor olmasıdır. Bu bakımdan övgü temalı şiirler konusunda Kays b. el-Hatîm'in diğer şairlere kıyasla kemiyet bakımından önde olduğunu söylemek mümkün gözükmektedir.

Şair övgü temalı beyitlerde davasını ve duygularını beyitlere yansıtmaya yoğunlaşmaktadır. Bu sebeple şairin yoğun sanat tasvirine dayalı mecaz dilinden uzak sade bir dil kullanmaya çalıştığı görülmektedir. Hal böyle olmakla birlikte الحرب ألقت رداءها ifadesindeki teşbih-i beliğ ve طعنت ابن عبد القيس طعنة ثائر cümlesindeki istiare-i mekniyye gibi edebî tasvir türlerine az da olsa rastlanmaktadır.

Şaire ait çalışma konusu beyitlerin kabîlecilik sistemine dayalı dönemin sosyal, kültürel ve zihinsel yapılarıyla ilgili ip uçları barındırdığı da açıktır. Nitekim Câhiliye toplumunda kabîleye aidiyet ve düşman karşısında kabîleyi bütün imkânlarla savunmak kabîlenin bekası için elzemdir. Evs b. el-Hatîm de sahip olduğu şiir becerisini bu gaye doğrultusunda kullanmakta ve mensubu bulunduğu Evs kabîlesini düşman karşısında bütün imkânlarla savunmaktadır. Yine ilgili beyitlerde kadın, içki, kan davası, el açıklığı vb. sosyal hayatta yaşanan veya savaş meydanlarında karşılaşılan hadiselerle ilgili detaylar söz konusudur. Şaire göre gönlü zengin kimse her daim zengin iken tamahkâr kimse ömür boyu bedbahttır. Yine şaire göre mal ve ahlâk, ödünç alınacak borçtan öte bir şey değildir. Bu bakımdan cimri kimsede hayır yoktur. Yine şaire göre sır iki kişiyi aşmış ise sır olmaktan çıkar ve dillere destan olur. Kuşkusuz bu türden yaklaşımlar dönemin kültürel ve zihinsel yapıları hakkında ip uçları barındırmaktadır. Çalışmanın bu yönüyle de sahada yapılacak çalışmalara katkı sağlaması ümit edilmektedir.

\section{Kaynakça}

'Abdunnûr, Cebbûr. el-Mu'cemu'I-edebî. Beyrut: Dâru'I-'ilm Li'I-Melâyîn, 1984.

Abkarius, İskender Aga. Kitâbu Ravdati'l-edeb fî tabakâti şu'arâi'l-'Arab. Beyrut: byy., 1858.

İsfâhânî, Ebu'I-Ferec. Kitâbu'l-ağânî. Thk. ỉbrahim es-Se'âfîn vd. Beyrut: Dâru Sâdır, 2008.

'Askalânî, Ahmed b. Ali b. Hâcer. el-isâbe fí temyîzi's-sahâbe. Thk. Abdullah b. Abdu'lMuhsin et-Turkî. Kahire: Merkezu Hecr Li'I-Buhûs ve'd-Dirâsâti'l-'Arabiyye Ve'lİslâmiyye, 2008.

'Askerî Ebû Hilâl. el-Furûk el-luğaviyye. Thk. Muhammed ibrâhîm Selîm. Kahire: Dâru'I-'ilm ve's-Sekâfe, 1997. 
Bağdâdî, 'Abdulkâdir b. 'Umar. Hızânetu'l-edeb. Thk. 'Abdussellâm Hârûn. Kahire: Mektebetu'I-Hâncî, 1996.

Bekrî Ebû 'Ubeyd. Faslu'l-makâal fí şerhi Kitâbi'l- emsâl. Thk. İhsân 'Abbâs ve 'Abdulmecîd 'Âbidîn. Beyrut: Dâru'l-Emâne, 1971.

Câhız, Ebû 'Usmân 'Amr b. Bahr. el-Hayavân. Thk. 'Abdussellâm Muhammed Hârûn. Kahire: Şeriketu Mektebeti ve Matba'ati Mustafa el-Bâbi el-'Halebî ve Evlâduh, 1965.

Cebbûrî, Munzir. Eyyâmu'l-'Arab ve eseruhâ fi'ş-şi'ri'l-Câhilî. Bağdâd: Dâru'ş-Şuûni'sSekâfiyye el-'Âmme, ts.

Celîl, Hasen Muhammed. Kays b. el-Hatîm hayâtuh ve şi'ruh. Amman: Dâru Dicle, ts.

Cundî, 'Ali. Şi'ru'l-ḥarb fi'l-'asri'l-câhilî. Beyrut: Dâru Mektebeti'l-Câmi'ah el-'Arabiyye, 1966.

Dayf, Şevkî. Târîhu'l-edebi'l-'Arabî el-'Asru'l-câhilî. Kahire: Dâru'l-Ma'ârif, 1960.

Ebu'r-Rabb, İbtisâm Nâyif Sâlih. Suvaru'l-ḥarb ve eb'âduha'l-ustûriyye fi'ş-şi'ri'l-câhilî. (Yüksek Lisans Tezi, Câmi'atu'n-Necâh el-Vataniyye, Nablus, 2006.)

Faysal, 'Abdul'azîz b. Muhammed. el-Edebu'l- 'Arabî ve târîhuh. Riyad: Câmi'atu'l-ìmâm Muhammed b. Su 'ûd el-i̇slâmiyye, 1405.

Halebî, Semîr. el-Kerem ve'l-cûd ve's-sahôa. Tanta: Dâru's-Sahâbe Li't-Turâs, 1988.

Hamevî, Şihâbuddîn Yâkût b. 'Abdullah er-Rûmî. Mu'cemu'l-buldân. Beyrut: Dâr Sâdır, 1977.

Hassân b. Sâbit. Dîvân. Thk. 'Abd Muhanna. Beyrut: Dâru'I-Kutubi'l-'ilmiyye, 1994.

İbn el-Esîr, el-Cezerî, Ebu'l-Hasen 'Ali b. Ebî'l-Kerem, Muhammed b. Muhammed b. 'Abdulkerîm, b. 'Abdu'l-Vâhid eş-Şeybânî. el-Kâmil fít-târîh. Thk. Ebu'l-Fidâ 'Abdullah el-Kâdî. Beyrut: Dâru'I-Kutubi'I-'Ilmiyye, 2003.

Ibn Habîb, Ebû Ca'fer Muhammed. Kitâbu'I-Muhabbar. Tsh. Eliza Lechten Stetter. Beyrut: Dâru'l-Âfâki'l-Cedîde, ts.

İbn Hazm, Ebû Muhammed 'Ali b. Ahmed b. Sa'id. Cemheretu ensâbi'l-'Arab. Thk. Kurul. Beyrut: Dâru'l-Kutubi'l- 'Illmiyye,1983.

İbn Manzûr. Lisânu'l-'Arab. Kahire: Dâru'l-Ma'ârif, ts.

İbn Raşîk, Ebû Ali el-Hasen el-Kayravânî. el-'Umde fî mahâsini'ş-şi'r ve âdâbihi ve nakdih. Thk. Muhammed Muhyiddîn Abdulhamîd. Beyrut: Dâru'l-Cîl, 1981.

İbn Sellâm, Muhammed el-Cumahî. Tabaḳātu fuḥûli'ş-şu'arâ'. Thk. Mahmûd Muhammed Şâkir. Cidde: Dâru'I-Medenî, ts.

İsmail Durmuş, "Kays b. Hatîm”, Türkiye Diyanet Vakfı İslâm Ansiklopedisi (Ankara: TDV Yayınları, 2002).

Kassâb, Velîd. Dîvânu 'Abdillâh b. Ravâha dirâse fî sîratih ve şi'rih. Riyad: Daru'l-'Ulûm, 1982.

Kays b. el-Hatîm. Dîvân. Thk. Nasıruddîn el-Esed. Beyrut: Dâru Sâdır, ts.

Kudâme b. Ca'fer. Naḳdu'ş-şi'r. Thk. Muhammed 'Abdulmun'im Hafâcî. Beyrut: Dâru'lKutubi'l- 'Ilmiyye, ts.

Kuraşî, Ebû Zeyd Muhammed b. Ebi'l-Hattâb. Cemheretu eş'âri'l-'Arab fíl-Câhiliyyeti ve'lisslâm. Thk. Muhammed 'Ali el-Hâşimî. Riyad: İmam Muhammad bin Sa'ud Islamic University, Comitte of Researc, Translation and Publication, 1981.

Kurtubî, Ebû 'Abdillâh Muhammed b. Ahmed b. Ebî Bekr. el-Câmi' li aḥkâmi'l-Ḳur'ân. Thk. 'Abdullâh b. 'Abdulmuhsin et-Turkî. Beyrut: Muessesetu'r-Risâle, 2006.

Merzubânî, Ebû 'Ubeydillâh Muhammed b. 'İmrân. Mu'cemu'ş-şu'arâ'. Tsh. F. Krenkov. Beyrut: Dâru'I-Kutubi'I-'ilmiyye, 1982.

Sakkâ, Mustafâ. Muhtâru'ş-şi'ri'l-câhilî. Beyrut: Dâru'l-Fikr, 2014.

Tâha, Ahmed ibrâhîm. Târîhu'n-nakdi'l-edebî 'inde'l-'Arab. Mekke: Mektebetu'l-Faysaliyye, 1937. 
Tebrîzî, Ebû Zekeriyâ Yahyâ b. 'Ali el-Hatîb. Şerḥu Dîvâni'l-ḥamâse. Thk. Muhammed Muhyiddîn el-Hatîb. Kahire: Matba'atu Hicâzî, 1938.

Tuleymât Gâzî ve el-Aşkar, 'İrfân. el-Edebu'l-câhilî ḳadâyâhu ağrâduh a'lâmuh funûnuh. Dimaşk: Mektebetu'l-Îmân, 1992.

Vehbe, Mecdî ve el-Muhendis, Kâmil. Mu'cemu'l-mustalahâti'l-'Arabiyye fi'l-lugati ve'ledeb. Beyrut: Mektebetu Lubnân, 1984.

Ziriklî Hayruddîn. el-'Alâm. Beyrut: Dâru'|- 'ilm Li'|-Melâyîn, 2002. 